\title{
Youth Well-Being in Brazil An Index for Cross-Regional Comparisons
}

\author{
Debora Dell’Aglio* \\ Wendy Cunningham** \\ Silvia Koller* \\ Vicente Cassepp Borges* \\ Joana Severo Leon*
}

World Bank Policy Research Working Paper 4189, April 2007

The Policy Research Working Paper Series disseminates the findings of work in progress to encourage the exchange of ideas about development issues. An objective of the series is to get the findings out quickly, even if the presentations are less than fully polished. The papers carry the names of the authors and should be cited accordingly. The findings, interpretations, and conclusions expressed in this paper are entirely those of the authors. They do not necessarily represent the view of the World Bank, its Executive Directors, or the countries they represent. Policy Research Working Papers are available online at http://econ.worldbank.org.

\footnotetext{
* Universidade Federal do Rio Grande do Sul, Brazil;** World Bank
} 


\section{Introduction}

Many studies present the status of youth in Brazil. They tell us about secondary education attainment rates (World Bank, 2000; Soares, Carvalho, Kipnis, 2003; Waiselfisz et al., 2004; Rodriguez and Herran, 2000), youth violence (Waiselfisz, 2004; Abramovay et. al., 2003; Abramovay and Rua, 2002; Human Rights Watch, 2003), youth unemployment (Bonelli, Reis, and Veiga 2004), youth participation (Weiss, 2004; Instituto Cidadania, 2004), and a myriad of other factors that we use to determine how well youth are surviving their transition from childhood to adulthood. ${ }^{1}$ While these various indicators are useful to understand the status of youth for a single indicator or, at best, in a single sector, they cannot be summed to give us a measure of the overall wellbeing of Brazilian youth. ${ }^{2}$ Instead, we are limited to discussing how well youth fare relative to adults or to other youth by comparing a list of single indicators. Some show youth are doing well while others show that they are not doing so well, making it difficult to assess the overall status across the many dimensions of youth well-being. Thus, it would be useful to have a single indicator that summarizes the multi-dimensionality of youth well-being in order to allow for comparisons across regions of Brazil as well as track progress over time as the Government, the non-governmental sector, communities, families, and youth work to improve the situation of Brazilian youth. ${ }^{3}$

Such an index was created for the United States by researchers at Duke University in the United States. The Child Well-Being Index (CWI) uses 28 key indicators in the areas of health, relationships, material goods, behavior, labor market, community, and emotional/spiritual well-being indicators to create a single index for children and youth in

\footnotetext{
${ }^{1}$ The period "youth" is difficult to define due to the many different criteria that can be used to specify the period. Some disciplines base it on biological change, such as the period when the body changes from being a child to being an adult. Others base it on economic transitions - being a household dependent to earning one's own keep - or social transitions - being a household dependent to being a household head. This leads to very different age periods to capture "youth", as well demonstrated by the wide range of ages used for youth policies or in research. The common thread among all these definitions is that the youth period is one of transition (World Bank, 2003; Lloyd 2004).

${ }^{2}$ Well-being has been defined as quality of life, and refers to objective and subjective aspects of the human existence (Cummins 1996). Objective aspects concerns facts or behavior, which can be operationally observed and measured. Subjective aspects are associated with perceptions of facts and behaviors of daily life.

${ }^{3}$ The international community is increasingly recognizing the need indices to measure welfare. The United Nations has created a Human Development Index, using four simple indicators. More recently, the Commonwealth Youth Programme-Caribbean Office has been developing a youth index for its member countries.
} 
the United States. ${ }^{4}$ Using the year 1975 as a base (taking a value of 100), the research teams have calculated the index every year, thus providing a measure of progress of children (roughly ages 0-17) both in the United States and in each state. Primary conclusions from the 1975-2003 period include the observation that children's well-being has not increased monotonically over time, but it fell in the 1980s and rose only slightly above its 1975 levels by 2003; the limited improvement is largely due to increasing obesity in the 1990s, but this has been counter-balanced by improvements in violence; and children of all races seem to be improving their well-being.

This study aims to construct a Brazilian Youth Well-Being Index (YWI), based on indicators that are appropriate to, and available in, Brazil. It uses readily available data to calculate the YWI for each state, thus allowing for a comparison of the well-being of youth across Brazil. The hope is that the paper will sufficiently present the methodology such that the exercise can be repeated annually, thus allowing a tracking of the well-being of youth in each state over time and monitoring the status of all youth in Brazil across time. ${ }^{5}$

Three indices are developed in this paper. First, the Youth Well-Being Index (YWI) is comprised of indicators that are relevant only to today's youth, defined as those age 15$24 .^{6}$ These indicators include many of those indicators that are reported for youth in the general literature, and classified into: behaviors (youth violence, teen pregnancy, substance use); health outcomes that are a result of risk-taking behaviors (HIV/AIDs

\footnotetext{
${ }^{4}$ The indicators, by domain, used by the Duke University study are: (i) material well-being - poverty rate, secure parental employment rate, median annual income, percent of children with health insurance coverage; (ii) social relationships - percent of children in families headed by a single parent, percent of children who moved in the last year; (iii) health - infant mortality rate, low birth weight rate, mortality rate ages 1-19, percent of children with very good/excellent health, percent of children with activity limitations, percent of overweight children and adolescents; (iv) safety/behavioral concerns - teenage birth rates; percent of violent crime victimization, percent of violent crime offenders, rate of cigarette smoking, rate of alcoholic drinking, rate of illicit drug use; (v) productivity (educational attainment) - reading test scores, mathematics test scores; (vi) place in community - percent of pre-school enrollment, percent of persons who have received a high school diploma, percent of youth not working and not in school, percent of people who have received a bachelor's degree, rate of voting in presidential elections; and (vii) emotional/spiritual well-being - suicide rate, rate of weekly religious attendance, percent who report religion as being very important.

${ }^{5}$ The CWI created by Duke University is reported regularly in the popular press (New York Times, National Public Radio) and is the subject of academic conferences and publications (Brookings Institute http://www.brook.edu/comm/events/20040324.htm, http://www.brookings.edu/es/ccf/pubs_index.htm)

${ }^{6}$ This is roughly the age range used in this paper. The exact age range could not be used since the exercise in this paper intentionally uses existing indicators, which themselves use a variety of age ranges.
} 
infection); school performance that can be a result of risk-taking behavior (such as low school attendance) or can be a predictor of limited future integration in society; and institutional connectedness ${ }^{7}$ - to school, the labor market, and to the political process (voting patterns).

The YWI is a static picture of youth today, but it is also possible to get an idea of how the youth of tomorrow will fare, by expanding the YWI to include indicators for children, via the Child-Youth Well-Being Index (C-YWI). The C-YWI expands our understanding of youth development beyond the situations facing 15-24 year old youth today and brings into consideration the importance of investments early in life that will prepare individuals once they reach the youth period. The C-YWI includes all those indicators used for the YWI as well as health, school performance, and institutional connectedness indicators pertaining to today's children. This is useful since it gives information not only about today's youth, but also about the next generation of youth.

Finally, a General Youth Well-Being Index (GYWI) is created, which includes the set of variables in the C-YWI, as well as factors that affect the environment in which children and youth learn their preferences, face their constraints, and make their decisions. This index is derived from a theory of youth development that posits that youth are products of their environment (Bronfenbrenner, 1979), so to measures the wellbeing of youth in a state, it is reasonable to include measures of the environment, as well. Kohler, et. al. (2005) found that low poverty, high parental education, presence of both parents in the household, and positive community well-being are important correlates of positive youth behaviors in Brazil. To capture these influences, a category of variables capturing the socioeconomic level of each state is included, which include factors such as poverty or the share of single-parent households.

\footnotetext{
${ }^{7}$ The concept of "connectedness" is commonly used in the public health literature to describe the extent to which a person feels a part of a relationship, institution, community, or other group (Blum 1997). Thus, for example, parental connectedness is not achieved by a parent simply spending time with a child, but instead it requires an interaction such that the child feels that the adult cares. Similarly, connectedness to school is a feeling of "belonging" which often results in continued attendance). While standard indicators do not capture "connectedness", we can measure a result of connectedness, which is participation in institutions, which may be a proxy of the less measurable concept.
} 


\section{Data and Methodology}

The Brazilian Youth Well-Being Index uses as its starting point the index created by Duke University, departing from it based on data availability and appropriateness of indicators for the Brazil case.

\section{Data}

Thirty-six indicators are used to construct the indices, which can be grouped into five categories (columns 1 and 2 of Table 1). ${ }^{8}$ Health includes indicators on infant mortality and on AIDS. Behavior variables are those that measure the outcomes of risktaking behaviors, such as adolescent pregnancy (a result of risky sex), homicide/suicide, and substance use. AIDS is not included here recognizing that, in some instance, it may not be a result of risk-taking behaviors. School performance includes graduation rates, literacy, average education, and performance on standardized tests. Institutional connectedness variables include young people's interaction with public institutions, including school, the labor market, and voting. Finally, the socioeconomic conditions include indicators related to poverty and household structure. The indicators in each category are presented in Table 1.

The indicators were selected based on two criteria. First, they must be indicators that are commonly used to track the well-being of youth and/or children. This includes indicators that are regularly used in various sectors to assess the situation of youth, indicators of childhood investment that have been shown to have significant impacts on the youth period, and general factors exogenous to the young person but important for his/her development (Bronfenbrenner, 1979, Kohler, 2004). ${ }^{9}$

Second, they must be easily available to allow for future researchers to replicate this exercise. Since the indices are calculated at the state level, the set of potential

\footnotetext{
${ }^{8}$ While the US CWI uses seven categories (or "domains," as used in Duke University, 2003), we collapse some of the categories from the US CWI, based on data availability and the youth development models that form the basis of the choice of variables for the Brazilian YWI.

${ }^{9}$ A commonly used model in the public health field to understand youth development is the ecological risk framework. The basic premise is that youth are a product of their own "hardwiring" and of their environment, which includes spheres of family, community, institutions, and the macro-environment). The correlation between a negative environment and negative youth behaviors has been found to be very strong in the United States (Blum, 2002), the Caribbean (World Bank, 2003), and Brazil (Kohler, et. al. 2005), and new evidence in the United States suggests causal relationships (Roche, Ahmed, and Blum).
} 
variables is more limited than if we used national indicators. The data used in this exercise are primarily from 2002, the most recent year for which most indicators were available. However, educational performance tests indicators and substance use indicators were only available for 2001. The source of the indicators is given in Table 2, and are easily accessible to the public.

Most of the indicators on socioeconomic status and connection to institutions were obtained from the Brazilian Institute of Geography and Statistics (Instituto Brasileiro de Geografia e Estatística - IBGE) and IPEA (Instituto de Pesquisa Econômica Aplicada - Institute of Applied Economic Studies). These institutions utilize census data and regular household surveys to calculate various indicators periodically, which are reported on the institutions' web pages.

A smaller set of indicators are taken from the administrative data of Ministries and other government institutions. The Ministry of Labor and Employment's data base was used to derive the share of the population in formal sector employment, defined as those with a signed work card (carteira de trabalho assinada). The RAIS database is a census of all workers with signed work cards, thus giving an exact count of formal sector workers, as well as basic demographic information that allows identifying the state of origin and age of workers, among other characteristics. To create a ratio, data from the 2000 Census, managed by the IBGE, was used.

The share of 16-17 year olds who vote was obtained from the Superior Electoral Court (Tribunal Superior Eleitoral) and IBGE. The former provides the number of people who voted in the 2002 elections, by state and age level. The latter is used to create a ratio.

The indicators for test scores and school attendance were reported on the Ministry of Education's administrative data bases. The scores on the math and Portuguese language tests are taken from the National System of Assessment in Basic Education (Sistema Nacional de Avaliação da Educação Básica - SAEB). These tests are given annually, across Brazil, to measure the progress of learning of Brazilian students in the $4^{\text {th }}, 8^{\text {th }}$ and $11^{\text {th }}$ grades (last year of education before tertiary).

Health indicators - neo-natal mortality, infant mortality, adolescent morbidity, and AIDS - were presented in the Ministry of Health data bases. Data on the hospital 
morbidity of adolescents due to external causes is taken from the Hospital Information System from the Unified Health System (Sistema de Informacoes Hospitalares do SUS), managed by the Ministry of Health and fed by information from hospitals at the municipal and state level. It provides information on most hospital admissions in Brazil, as well as the reason the patient was omitted to the hospital. Admissions due to homicide, traffic accidents, suicide, and firearms are classified as "external causes.” The AIDS rates (per 100,000 individuals) were calculated by the Ministry of Health data, which identifies age and state of residence of each AIDS sufferer. Again, the 2000 Census data are used to create the indicator.

Finally, a few indicators are derived from very specific studies. The separate indicator for "homicide rate" and "suicide rate" in Table 1 are distinct from "external causes.” They are derived from the Violence Map IV, which was constructed by UNESCO, the Presidential Special Office for Human Rights, and the Ayrton Senna Institute. The choice was made to include both "external causes" and "homicide rate" in the calculation of our indices since adolescent victims of homicide are not always admitted to hospitals. Similarly with "suicide rates," since they may be classified as death due to accidental factors rather than as a violent act in itself.

Indicators concerning the use of alcohol, tobacco, marijuana, and cocaine were obtained from the (First) Household Survey on the Use of Psychotropic Drugs in Brazil, from CEBRID (2001). The survey encompassed a sample across the 107 largest cities in Brazil, which included all cities with more than 200,000 inhabitants and all state capitals. The indicators presented by CEBRID are regional indices, so for the purposes of creating the indices in this paper, each state was assigned the value of the region where the state lies.

\section{Methodology}

Three indices are calculated in this paper; the indicators included in each index are indicated in Table 1. The Youth Well-Being Index includes only those indicators pertinent to adolescents, principally ages 15-24. Not all indicators span this specific age period, since different institutions use different age cut-offs in the creation of their indicators. The Child-Youth Well-Being Index includes all the indicators in the YWI as 
well as additional health, school, and institutional indicators that pertain to those age 014. The General Well-Being Index includes all indicators in the table, thus capturing the actions of youth today, the "head start” that tomorrow's youth are getting, and the general environment in which they are growing up.

The creation of the index is not as simple as summing the indicators since all are on different scales. Instead, it is necessary to standardize each indicator on a single scale and to use that transformed value to generate the index.

Since high values of some indicators indicate greater well-being, such as higher test scores, while high values in other indicate poor well-being, such as homicide rates, it is necessary to convert the values such that the magnitude of the index had meaning. For this exercise, we assume that a high standardized value indicates high well-being. Thus, to standardize the value of those indicators that have higher values for high well-being, the following formula is used:

$$
I S_{j s}=\frac{I_{j s}-I_{j}}{\sigma_{j}} * 10+100
$$

Where $I_{\mathrm{js}}$ is the standardized indicator $\mathrm{j}(\mathrm{j}=1 . .25$ for the YWI; $\mathrm{j}=1 . .31$ for the C-YWI; and $j=1 \ldots 36$ for the GYWI) for state $s(s=1 \ldots 27), I_{j s}$ is the gross value of indicator $j$ for state $s, I_{j}$ is the gross value of indicator $j$ for the whole country, and the denominator is the standard error of indicator $\mathrm{j}$ for the country. The national-level mean is generated by summing the state-level indicator values and dividing by the number of states (27). Thus, the $I_{j}$ is not weighted by the population size of the state. This assumption was driven by the data since some of the indicators did not have a nationally-weighted $\mathrm{I}_{\mathrm{j}}$. If we let $\mathrm{I}_{\mathrm{js}}=\mathrm{I}_{\mathrm{j}}$, then $\mathrm{I}_{\mathrm{js}}=100$; i.e. the national average takes a value of 100 , and is a base against which all $\mathrm{IS}_{\mathrm{js}}$ can be compared.

For those indicators where a higher value indicates lower well being:

$$
I S_{j s}=-\frac{I_{j s}-I_{j}}{\sigma_{j}} * 10+100
$$

The simple mean of the standardized scores is calculated for each state (s):

$$
I_{s}=\frac{\sum_{j=1}^{n_{i}} I S_{s j}}{n}
$$


Where $n_{i}=25$ for $i=1$, corresponding to the YWI; $n_{i}=31$ for $i=2$, corresponding to the $C$ YWI; and $n_{i}=36$ for $i=3$, corresponding to the GYWI. $I_{s}$ is the index for state $s=1 \ldots 27$.

This method assumes an equal weighting of each indicator. While it may be argued that some variables should carry a higher weight, the literature does not indicate how to best weight such a diverse set of indicators. ${ }^{10}$

The raw value of the indicators and the standardized score for each indicator and each state is given in Annexes 1-5. Each table presents the indicators for each of the five categories of indicators being used: health, behaviors, school performance, institutional connectedness, and socioeconomic characteristics.

\section{Results}

\section{Youth Well-Being Index}

The Youth Well-Being Index shows that youth in the Northeast are the worst off, while those in the Central-West and Southeastern states are faring the best (Table 3). Youth in Penambuco and Alagoas have the lowest scores, faring six and 5.3 percent worse than all Brazilian youth across the full range of indicators (Figure 1). Both states have very low ratings in all youth behaviors, school performance, and connection to local institutions, while most other states excel in some areas more than others. Youth in Santa Catarina and the Federal District fare 6.1 and 5.1 percent better than the national average. Their higher than average performance can be attributed to particularly high school performance, school advancement and formal sector employment in Santa Catarina and employment opportunities, secondary education attendance, school performance, and low substance abuse in the Federal District.

While the YWI neatly ranks the states by the well-being of its young constituents, a disaggregation of the index shows that the well-being of youth is not consistently good or bad across categories. For example, while the Federal District has the highest ranking

\footnotetext{
${ }^{10}$ The US CWI gives an equal weighting to each category of variables, thus calculating $\mathrm{I}_{\mathrm{s}}$ for each of the seven groups of variables, then summing the indicator and dividing by seven. This necessarily gives higher weight to each indicator in a category with fewer variables, which is based on data availability, rather than a judgment of the greater importance of those variables. To avoid such spurious assignment of importance to variables based on how indicators are entered into the equations, we take a simple mean across all variables, giving equal weight to each.
} 
on the YWI, and ranks first in connectedness to institutions, it ranks $17^{\text {th }}$ (of 27) in health. Conversely, Amazonas ranks $23^{\text {rd }}$ overall, but it ranks fifth in the health indicators. The correlation between the ranking for the YWI and categories of indicators is very low for health and behaviors - 0.3 and 0.22 respectively - and very high for school performance (0.81). The correlation between the YWI and socioeconomic indicators, which are exogenous to the YWI is also fairly high, at 0.68 (last row of Table 3).

Both the indicators that comprise the health category have high values for the Southern states and low values for the Northern states (Annex 1). The incidence of AIDS is reported to be consistently higher in the Southern states (14 per 100,000 youth) and lower in the Northeast (3 per 100,000 youth) (Figure 2). For example, nine states, all in the North and Northeast, report zero AIDS incidence among 10-17 year olds in 2002. This may be linked due to the fact that the epidemic started in the Southeast and is still concentrated, while incidence is lower, but increasing, in the North and Northeastern Regions (NAH/MoH, 2005). Related to this is the significant under-reporting in the North and Northeast, partly due to fewer for well-trained professionals to identify and report AIDS incidence as the epidemic grows in these areas (NAH/MoH, 2005).

The behavior category, with eight indicators, is not as consistently skewed, but a few indicators stand out, particularly in the Southeast (Figure 3). Homicide rates in the Southeast, the home of Rio de Janeiro and São Paulo, are particularly elevated. While fewer than 50 of every 100,000 youth die of homicide in the other four regions, nearly 84 do in the Southeast. Alcohol and tobacco use is also much higher in the South and Southeast than in the rest of the country (Annex 2).

Further disaggregating the indicator categories, a few specific behaviors are worth noting due to their importance in determining the future of Brazil's youth and their high variance across the country. In the Northern and Northeastern states, adolescent pregnancy rates were higher. They varied from 26.8 percent in Tocatins to 16.5 percent in the Federal District to (national average of 21.8 percent). This is a concern since early pregnancy increases mortality rates for women and their children (Pinto e Silva, 1998, www.ibge.gov.br).

In terms of participation in educational and labor institutions (Annex 3 \& 4), youth connectedness to the former breaks earlier and connectedness to the latter begins 
earlier in the Northeastern states. While most regions have school participation rates of 15-17 year olds that exceed 80 percent, all Northeastern states show rates below 80 percent, with the exception of Bahia. Further, the share of 10-17 year olds working and studying exceeds 25 percent in several states in the Northeast (Piaú, Ceará, Maranhão), unlike in the rest of the country. This is not to say that youth in other states do not have close connections with institutions, as shown by the difficulty of labor force attachment by youth in the Southeast, where they both enter the workforce early (about 22 percent of 10-17 year olds are working) and they face the highest unemployment rates.

The North and Northeast do not fare poorly in all indicators, though, as they show much greater rates of political participation than do youth elsewhere. More than half of 16-17 year olds voted in the 2002 elections in four Northern (of 7) and three Northeastern (of 9) states. The voting rates rarely exceeded 35 percent in the other regions.

\section{Brazilian Child-Youth Well-Being Index}

To capture how well each state in Brazil is preparing its youth of tomorrow, the YWI is expanded to include measures of investment in today's children. This expansion

addresses some of the methodological issues discussed above, such as additional variance in the health category, with the addition of two new indicators.

The Child-Youth Well-Being Index (C-YWI) closely tracks the YWI (Figure 4), suggesting that the well-being of youth in each state in the near future will continue to rank similarly to that of this generation (correlation coefficient of 0.91). The five states with the best YWI scores - Federal District, Santa Catarina, Goiás, São Paulo, and Minas Gerais - have the top C-YWI scores, though the ordering has slightly changed (Table 4). Similarly, the bottom seven scores - Pernambuco, Alagoas, Amapá, Maranhão, Amazonas, Piauí, Paraíba, Bahia, and Acre - have the lowest C-YWI scores, as well. While most of the rankings are similar, there are a few notable changes when including the well-being of children.

The biggest change is the state of Rio de Janeiro, which moves from a ranking of 14 to 6 when the additional variables are added (Table 4). The primary factors behind this movement are in the health and institutional connectedness categories. In health, the poor AIDS rates are off-set by low infant mortality and low neo-natal mortality rates. 
Rio de Janeiro is among the top six states in controlling these factors. Furthermore, while the AIDS rates of 0-10 year old children in Rio de Janeiro are above the national average, the rates are below those of the other states in the South, Southeast, and Central West, with the exception of the state of São Paulo and the Federal District. School attendance among 0-3 year old and 4-6 year old children in Rio de Janeiro is also among the top six performing state. This investment in early childhood education is likely to have significant impact on the future youth population, as various studies have shown a connection between early childhood investments and lower violence and substance abuse, better school attendance and performance, and greater job attachment and higher earnings as adults (Schweinhart, 2004). Furthermore, Rio de Janeiro and São Paulo children have the highest rates of fourth grade completion, and are likely obtaining the behavioral, as well as pedagical benefits, from greater school attendance (Blum 2002).

The states of Paraná, Ceará, and Espiritu Santo also improved their ranking with the addition of the childhood variables, though the responsible factors differ by state. The responsible factors in Parana were health and $4^{\text {th }}$ grade completion; in Ceará, early childhood education was particularly high relative to the rest of the country; and children in Espiritu Santo had above average good performance in all the child variables.

The states that significantly fall in the rankings are Rio Grande do Sul, Rondonia, Pará, and, particularly, Tocatins (Table 4). The state of Tocatins falls from a ranking of seventh to $15^{\text {th }}$ - the national average - with the addition of the child variables. The factors most responsible are average performance in the health variables and the worst performance of all the states in early childhood education and the second-lowest in preschool education attendance rates. Rio Grande do Sul performed well in all the new variables except pre-school (age 4-6) education, where the state had the lowest rates (48.1 percent) in Brazil. This is surprising since early childhood (age 0-3) is above the national average. Rondônia also scores poorly in early childhood education and pre-school, but its health indicators are above the national average. Finally, children from Pará are at the national average for all the new indicators except graduation from $4^{\text {th }}$ grade, where Pará has almost the worst performance in Brazil. 


\section{General Youth Well-Being Index}

The addition of the socioeconomic variables to the C-YWI gives us the General Youth Well-Being Index (GYWI), which finds that most states retain their ranking with a few exceptions (Figure 4, Table 4). The top five are joined by Rio de Janeiro, due to above average levels of wealth, formal sector employment opportunities, and health care accessibility, relative to the rest of Brazil. The bigger issue in the state of Rio de Janeiro, which is not captured by these indicators, is access to these factors, since their youth are faring particularly poorly given the relative wealth of the state, relative to most of the other states in Brazil. The bottom eight ranking states are still the bottom ranking states. This is not surprising since they are among the poorest states, so they perform poorly in the socioeconomic category (Table 3, last column).

Besides Rio de Janeiro, the only other significant change in ranking was observed for Espíritu Santo, where the YWI ranking was $18^{\text {th }}$, the C-YWI ranking was $14^{\text {th }}$, and the GYWI ranking was $11^{\text {th }}$. The last improvement is due to better than average rankings in all the socioeconomic indicators, with the exception of a formal sector employment rate, equivalent to the national average (Annex 5). This has the result of raising the state to a ranking higher than the median position.

There were not significant declines in rank, either. However, it is notable that Rio Grande do Sul regained some of the position it lost when the child variables were added. It moved from $10^{\text {th }}$ position in the C-YWI to $8^{\text {th }}$ in the GYWI. This is still not as good as its $6^{\text {th }}$ place ranking in the YWI, but it does suggest that the future of Rio Grande do Sul youth is perhaps better than the C-YWI would indicate. The improvement in ranking is due to its very high rankings in dual parent households, number of physicians per 1000 inhabitants, and low poverty (household income per capita) (Annex 5).

\section{Conclusions}

The Brazilian Youth Well-Being Index shows that the situation of youth across Brazil varies greatly. While youth in some states, such as the Federal District and Santa Catarina, are doing well across nearly all indicators, others, particularly those in the Northeast and the North, consistently perform poorly. To track the progress of these 
states in addressing the problems facing youth today, and in the future, it will be important to regularly re-calculate the index and observe its progress over time.

The three indices presented in this paper - the Youth Well-Being Index, Child-Youth Well-Being Index, and the General Youth Well-Being Index - are a Brazilian adaptation of the US-based Youth Well-Being Index, taking into consideration the factors that are important to the Brazilian context and the availability of data. They use different sets of variables to come up with a single measure of well-being for youth today (YWI) and for youth today and in the next generation (C-YWI). The GYWI takes into consideration the hypothesis from the ecological risk framework and includes in the measure environmental factors that affect child and youth development. These three indicators show very similar state rankings, suggesting that any of the three may be used to track youth progress. However, the similarity across indices also suggests that the situation of youth in Brazil is relatively static, since the states that have the poorest youth well-being indicators today are not making necessary investments to correct the situation for the future.

The index presented has some methodological shortcomings to address as the tool is used and refined. First, the quality of some of the indicators is questionable. Notably, the AIDS incidence indicators deserve further examination to ascertain their quality. Second, the alcohol and drug use indicators are from a special survey that reports results at the regional level. This survey will need to be repeated regularly and the results reported at the state level to provide greater variance and updating of the indicators for use in the index. A more random sample to include small cities and rural areas would also improve the quality of these indicators and thus the quality of the index. Third, information on new youth issues, such as obesity, incarceration/rehabilitation or youth participation, would further improve the applicability of the index to the Brazilian youth context. 
Table 1: Indicators Used to Construct the Indices

\begin{tabular}{|c|c|c|c|c|c|}
\hline \multirow[t]{2}{*}{ Category } & \multirow[t]{2}{*}{ Indicator } & \multicolumn{3}{|c|}{$\begin{array}{l}\text { Index for which the } \\
\text { Indicator is Used }\end{array}$} & \multirow[t]{2}{*}{ Year } \\
\hline & & $\begin{array}{c}\text { Youth } \\
\text { WI }\end{array}$ & $\begin{array}{c}\text { Child- } \\
\text { Youth WI }\end{array}$ & $\begin{array}{c}\text { General } \\
\text { WI }\end{array}$ & \\
\hline \multirow{5}{*}{ Health } & Infant mortality rate $(0-1)$ & & $\mathrm{X}$ & $\mathrm{X}$ & 2002 \\
\hline & Post-Neonatal mortality rate (28-365 days) & & $\mathrm{X}$ & $\mathrm{X}$ & 2002 \\
\hline & Share of 0-10 year olds with AIDS & & $\mathrm{X}$ & $\mathrm{X}$ & 2002 \\
\hline & Share of $11-17$ year olds with AIDS & $\mathrm{X}$ & $\mathrm{X}$ & $\mathrm{X}$ & 2002 \\
\hline & Share of 18-24 year olds with AIDS & $\mathrm{X}$ & $\mathrm{X}$ & $\mathrm{X}$ & 2002 \\
\hline \multirow[t]{8}{*}{ Behavior } & Pregnancy rate - live births (age 15-19) & $\mathrm{X}$ & $\mathrm{X}$ & $\mathrm{X}$ & 2002 \\
\hline & Suicide rate (age $15-24$ ) & $\mathrm{X}$ & $\mathrm{X}$ & $\mathrm{X}$ & 2002 \\
\hline & Homicide rate (age 15-24) & $\mathrm{X}$ & $\mathrm{X}$ & $\mathrm{X}$ & 2002 \\
\hline & Morbidity rate due to “external causes” (females age 15-19) & $\mathrm{X}$ & $\mathrm{X}$ & $\mathrm{X}$ & 2002 \\
\hline & Share of 12-17 year olds who have used alcohol & $\mathrm{X}$ & $\mathrm{X}$ & $\mathrm{X}$ & 2001 \\
\hline & Share of 12-17 year olds who have used tobacco & $\mathrm{X}$ & $\mathrm{X}$ & $\mathrm{X}$ & 2001 \\
\hline & Share of 12-17 year olds who have used marijuana & $\mathrm{X}$ & $\mathrm{X}$ & $\mathrm{X}$ & 2001 \\
\hline & Share of 12-17 year olds who have used cocaine & $\mathrm{X}$ & $\mathrm{X}$ & $\mathrm{X}$ & 2001 \\
\hline \multirow{9}{*}{$\begin{array}{l}\text { School } \\
\text { Performance }\end{array}$} & Share of $4^{\text {th }}$ graders who complete the grade level & & $\mathrm{X}$ & $\mathrm{X}$ & 2002 \\
\hline & Share of $8^{\text {th }}$ graders who complete the grade level & $\mathrm{X}$ & $\mathrm{X}$ & $\mathrm{X}$ & 2002 \\
\hline & Share of $11^{\text {th }}$ graders (ensino medio) who complete the grade level & $\mathrm{X}$ & $\mathrm{X}$ & $\mathrm{X}$ & 2002 \\
\hline & Literacy rate (15-24) & $\mathrm{X}$ & $\mathrm{X}$ & $\mathrm{X}$ & 2002 \\
\hline & Score on Portuguese language test, $8^{\text {th }}$ graders & $\mathrm{X}$ & $\mathrm{X}$ & $\mathrm{X}$ & 2001 \\
\hline & Score on math test, $8^{\text {th }}$ graders & $\mathrm{X}$ & $\mathrm{X}$ & $\mathrm{X}$ & 2001 \\
\hline & Score on Portuguese language test, $11^{\text {th }}$ graders & $\mathrm{X}$ & $\mathrm{X}$ & $\mathrm{X}$ & 2001 \\
\hline & Score on math test, $11^{\text {th }}$ graders & $\mathrm{X}$ & $\mathrm{X}$ & $\mathrm{X}$ & 2001 \\
\hline & Average years of education of the 14 year old population & $\mathrm{X}$ & $\mathrm{X}$ & $\mathrm{X}$ & 2002 \\
\hline \multirow{3}{*}{$\begin{array}{l}\text { Institutional } \\
\text { Connectedness }\end{array}$} & School attendance rates of $0-3$ year olds & & $\mathrm{X}$ & $\mathrm{X}$ & 2002 \\
\hline & School attendance rates of $4-6$ year olds & & $\mathrm{X}$ & $\mathrm{X}$ & 2002 \\
\hline & School attendance rates of $7-14$ year olds & $\mathrm{X}$ & $\mathrm{X}$ & $\mathrm{X}$ & 2002 \\
\hline
\end{tabular}




\begin{tabular}{|c|c|c|c|c|c|}
\hline & School attendance rates of 15-17 year olds & $\mathrm{X}$ & $\mathrm{X}$ & $\mathrm{X}$ & 2002 \\
\hline & Unemployment rate of $15-24$ year olds & $\mathrm{X}$ & $\mathrm{X}$ & $\mathrm{X}$ & 2002 \\
\hline & Activity rate (in school or working) of 10-17 year olds & $\mathrm{X}$ & $\mathrm{X}$ & $\mathrm{X}$ & 2002 \\
\hline & Share of 10-17 year olds without any activity & $\mathrm{X}$ & $\mathrm{X}$ & $\mathrm{X}$ & 2002 \\
\hline & Share of working 16-24 years olds in formal sector jobs (com carteira assinada) & $\mathrm{X}$ & $\mathrm{X}$ & $\mathrm{X}$ & 2002 \\
\hline & Share of 16-17 year olds who vote & $\mathrm{X}$ & $\mathrm{X}$ & $\mathrm{X}$ & 2002 \\
\hline \multirow{5}{*}{$\begin{array}{l}\text { Socioeconomic } \\
\text { Conditions }\end{array}$} & Share of people below the poverty line & & & $\mathrm{X}$ & 2002 \\
\hline & Average household income per capita & & & $\mathrm{X}$ & 2002 \\
\hline & Proportion of the workforce with a signed work contract (formal sector) & & & $\mathrm{X}$ & 2002 \\
\hline & Number of physicians per 1000 habitants & & & $\mathrm{X}$ & 2002 \\
\hline & Share of single mother households & & & $\mathrm{X}$ & 2002 \\
\hline
\end{tabular}


Table 2: Data Sources

\begin{tabular}{|c|c|}
\hline Indicadors & Source \\
\hline \multicolumn{2}{|l|}{ Health } \\
\hline $\begin{array}{l}\text { Infant ( } 0 \text { a } 1 \text { ano) and } \\
\text { post-neonatal (1-12 } \\
\text { months) mortality }\end{array}$ & $\begin{array}{l}\text { Brazilian Institute of Geography and Statistics (IBGE) - Síntese } \\
\text { de Indicadores Sociais } 2003 \text { - Diretoria de Pesquisas, } \\
\text { Coordenação de População e Indicadores Sociais, Estatísticas do } \\
\text { Reqistro Civil 2002. www.ibge.gov.br }\end{array}$ \\
\hline $\begin{array}{l}\text { Share of } 0-10 \text { year } \\
\text { olds, } 11-17 \text { year olds } \\
\text { and } 18-24 \text { year olds } \\
\text { with AIDS. }\end{array}$ & $\begin{array}{l}\text { Ministry of Health. Programa Nacional de DST e Aids - Dados e } \\
\text { Pesquisas. Data from 2002.www.aids.gov.br. }\end{array}$ \\
\hline \multicolumn{2}{|l|}{ Behaviors } \\
\hline $\begin{array}{l}\text { Adolescent pregnancy } \\
\text { rate - live births (age } \\
\text { 15-19) }\end{array}$ & $\begin{array}{l}\text { Brazilian Institute of Geography and Statistics (IBGE) - Síntese } \\
\text { de Indicadores Sociais 2003. Diretoria de Pesquisas, } \\
\text { Coordenação de População e Indicadores Sociais, Estatísticas do } \\
\text { Registro Civil 2002. www.ibge.gov.br on 10/09/2004 }\end{array}$ \\
\hline $\begin{array}{l}\text { Adolescent suicide } \\
\text { and homicide } \\
\text { victimization rate } \\
\text { (age } 15-24 \text { ) }\end{array}$ & $\begin{array}{l}\text { UNESCO - Mapa da violência IV: Os Jovens do Brasil } \\
\text { www.ibge.gov.br, 12/06/2004 }\end{array}$ \\
\hline $\begin{array}{l}\text { Adolescent morbidity } \\
\text { rate due to "external } \\
\text { causes" (age 15-19) }\end{array}$ & $\begin{array}{l}\text { Ministry of Health- Sistema de Informações Hospitalares do SUS } \\
\text { (SIH/SUS) - 2002. } \\
\text { www.tabnet.datasus.gov.br/cgi/tabcgi.exe?sih/cnv/eruf.def, } \\
\underline{06 / 09 / 2004}\end{array}$ \\
\hline $\begin{array}{l}\text { Ever used alcohol, } \\
\text { tobacco, marijuana, } \\
\text { cocaine (age 12-17) }\end{array}$ & $\begin{array}{l}\text { Carlini, et. al. (2002) I Levantamento sobre o Uso de Drogas } \\
\text { Psicotrópicas no Brasil - } 2001 .\end{array}$ \\
\hline \multicolumn{2}{|c|}{ Educational Performance } \\
\hline $\begin{array}{l}\text { Share of } 4 \text { th, } 8 \text { th, and } \\
\text { 11th graders who } \\
\text { complete the grade } \\
\text { level }\end{array}$ & $\begin{array}{l}\text { Ministry of Education/INEP/EDUDATABRASIL - Sistema de } \\
\text { Estatísticas Educaçionais - 2002. } \\
\text { www.edudatabrasil.inep.gov.br, 06/09/2004 }\end{array}$ \\
\hline $\begin{array}{l}\text { Scores of 8th and } \\
\text { 11th graders on } \\
\text { Portuguese and math } \\
\text { standardized tests }\end{array}$ & $\begin{array}{l}\text { Ministry of Education (MEC)/Instituto Nacional de Estudos e } \\
\text { Pesquisas Educaçionais/Sistema Nacional de Avaliação da } \\
\text { Educação Básica (SAEB)- 2001. } \\
\text { www.inep.gov.br/basica/saeb/estados_2004.htm, 28/08/2004 }\end{array}$ \\
\hline $\begin{array}{l}\text { Average years of } \\
\text { education of the } 14 \\
\text { year old population }\end{array}$ & $\begin{array}{l}\text { Brazilian Institute of Geography and Statistics (IBGE) - Síntese } \\
\text { de Indicadores Sociais } 2003 \text { - Diretoria de Pesquisas, } \\
\text { Coordenação de População e Indicadores Sociais, Pesquisa } \\
\text { Nacional por Amostra de Domicílios 2002. www.ibge.gov.br, } \\
\text { 10/09/2004. }\end{array}$ \\
\hline
\end{tabular}




\begin{tabular}{|c|c|}
\hline $\begin{array}{l}\text { School attendance } \\
\text { rates of } 0-3,4-6,7- \\
14 \text {, and } 15-24 \text { year } \\
\text { olds. }\end{array}$ & $\begin{array}{l}\text { Brazilian Institute of Geography and Statistics (IBGE) - Síntese } \\
\text { de Indicadores Sociais } 2003 \text { - Diretoria de Pesquisas, } \\
\text { Coordenação de População e Indicadores Sociais, } \text { Pesquisa } \\
\text { Nacional por Amostra de Domicílios 2002. www.ibge.gov.br, } \\
\text { 10/09/2004. }\end{array}$ \\
\hline $\begin{array}{l}\text { Unemployment rate } \\
\text { of } 15-24 \text { year olds }\end{array}$ & $\begin{array}{l}\text { Brazilian Institute of Geography and Statistics (IBGE) - Síntese } \\
\text { de Indicadores Sociais } 2003 \text { - Diretoria de Pesquisas, } \\
\text { Coordenação de População e Indicadores Sociais, Pesquisa } \\
\text { Nacional por Amostra de Domicílios 2002. www.ibge.gov.br, } \\
\text { 10/09/2004. }\end{array}$ \\
\hline $\begin{array}{l}\text { Proportion of } 10-17 \\
\text { year olds who work } \\
\text { or work and study }\end{array}$ & $\begin{array}{l}\text { Brazilian Institute of Geography and Statistics (IBGE) - Síntese } \\
\text { de Indicadores Sociais 2003, Diretoria de Pesquisas, } \\
\text { Coordenação de População e Indicadores Sociais, Pesquisa } \\
\text { Nacional por Amostra de Domicílios 2002. www.ibge.gov.br, } \\
\text { 10/09/2004. }\end{array}$ \\
\hline $\begin{array}{l}\text { Proportion of } 10-17 \\
\text { year olds who neither } \\
\text { work nor study }\end{array}$ & $\begin{array}{l}\text { Brazilian Institute of Geography and Statistics (IBGE) - Síntese } \\
\text { de Indicadores Sociais 2003. Diretoria de Pesquisas, } \\
\text { Coordenação de População e Indicadores Sociais, Pesquisa } \\
\text { Nacional por Amostra de Domicílios 2002. www.ibge.gov.br, } \\
\text { 10/09/2004. }\end{array}$ \\
\hline $\begin{array}{l}\text { Proportion of } 16-24 \\
\text { year olds in the labor } \\
\text { force with formal } \\
\text { sector employment }\end{array}$ & $\begin{array}{l}\text { Ministério do Trabalho e Emprego/Relação Anual das } \\
\text { Informações Sociais (RAIS)/ Informações para o Sistema Público } \\
\text { de Emprego e Renda - 2002. www.mte.gov.br, 03/09/2004. }\end{array}$ \\
\hline $\begin{array}{l}\text { Proportin of } 16-17 \\
\text { year olds who voted } \\
\text { in the } 2002 \text { elections }\end{array}$ & $\begin{array}{l}\text { Tribunal Superior Eleitoral (TSE) - Eleições 2002/ Estatística do } \\
\text { Eleitorado por Sexo e Faixa Etária - Pesquisa por UF. } \\
\text { www.tse.gov.br, 17/06/2004. }\end{array}$ \\
\hline \multicolumn{2}{|l|}{ Socioeconomic Status } \\
\hline $\begin{array}{l}\text { Share of people } \\
\text { below the poverty } \\
\text { line }\end{array}$ & $\begin{array}{l}\text { IPEA (Instituto de Pesquisa Econômica Aplicada). Dados } \\
\text { Regionais - Brasil - Indicadores Sociais - Renda - } 2002 . \\
\text { www.ipedata.gov.br }\end{array}$ \\
\hline $\begin{array}{l}\text { Average household } \\
\text { income per capita }\end{array}$ & $\begin{array}{l}\text { IPEA (Instituto de Pesquisa Econômica Aplicada). Dados } \\
\text { Regionais - Brasil - Indicadores Sociais - Renda - } 2002 . \\
\text { www.ipedata.gov.br }\end{array}$ \\
\hline $\begin{array}{l}\text { Share of workforce } \\
\text { with a signed work } \\
\text { contract (formal } \\
\text { sector) }\end{array}$ & $\begin{array}{l}\text { IPEA (Instituto de Pesquisa Econômica Aplicada). Dados } \\
\text { Regionais - Brasil - Indicadores Sociais - Mercado de Trabalho } \\
\text { - 2002. www.ipedata.gov.br }\end{array}$ \\
\hline $\begin{array}{l}\text { Number of physicians } \\
\text { per } 1000 \text { habitants }\end{array}$ & $\begin{array}{l}\text { IBGE, Diretoria de Pesquisas, Departamento de População e } \\
\text { Indicadores Sociais, Pesquisa e Assistência Médico-Sanitária - } \\
\text { 2002. www.ibge.gov.br }\end{array}$ \\
\hline
\end{tabular}




\begin{tabular}{l|l}
\hline Share of single & IBGE - Síntese dos Indicadores Sociais 2003 - Diretoria de \\
mother households & $\begin{array}{l}\text { Pesquisas, Coordenação de População e Indicadores Sociais, } \\
\text { Pesquisa Nacional por Amostra de Domicílios 2002. } \\
\text { www.ibge.gov.br }\end{array}$ \\
\hline
\end{tabular}


Table 3: State Ranking for each Category of Indicators and the YWI

\begin{tabular}{|c|c|c|c|c|c|c|c|}
\hline \multirow[t]{2}{*}{ State } & \multirow[t]{2}{*}{ Region* } & \multirow[t]{2}{*}{$\begin{array}{l}\text { YWI } \\
\text { Rank }\end{array}$} & \multicolumn{4}{|c|}{$\begin{array}{c}\text { Ranking of Sub-Category of } \\
\text { the YWI }\end{array}$} & \multirow{2}{*}{$\begin{array}{l}\text { Socioeconomic } \\
\text { Rank } \\
\text { (not used to } \\
\text { generate the } \\
\text { YWI) }\end{array}$} \\
\hline & & & 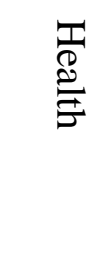 & 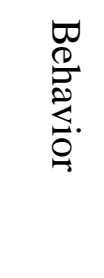 & 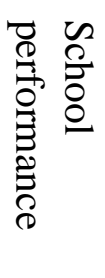 & 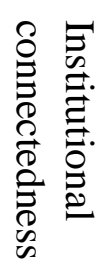 & \\
\hline Distrito Federal & $\mathrm{CW}$ & 1 & 17 & 3 & 4 & 1 & 1 \\
\hline Santa Catarina & $\mathrm{S}$ & 2 & 22 & 20 & 1 & 2 & 5 \\
\hline Goiás & $\mathrm{CW}$ & 3 & 3 & 1 & 11 & 13 & 10 \\
\hline São Paulo & $\mathrm{CE}$ & 4 & 21 & 24 & 2 & 3 & 3 \\
\hline Minas Gerais & $\mathrm{CE}$ & 5 & 1 & 17 & 5 & 14 & 11 \\
\hline Rio Grande do Sul & $\mathrm{S}$ & 6 & 27 & 21 & 3 & 11 & 4 \\
\hline Tocatins & $\mathrm{N}$ & 7 & 10 & 2 & 15 & 19 & 22 \\
\hline Roraima & $\mathrm{N}$ & 8 & 2 & 14 & 14 & 8 & 13 \\
\hline Rondônio & $\mathrm{N}$ & 9 & 11 & 7 & 10 & 24 & 12 \\
\hline Mato Grosso & $\mathrm{CW}$ & 10 & 4 & 12 & 12 & 21 & 9 \\
\hline Mato Grosso do Sul & $\mathrm{CW}$ & 11 & 9 & 18 & 9 & 15 & 7 \\
\hline Paraná & $\mathrm{S}$ & 12 & 18 & 19 & 7 & 7 & 6 \\
\hline Pará & $\mathrm{N}$ & 13 & 6 & 4 & 17 & 20 & 19 \\
\hline Rio de Janeiro & $\mathrm{CW}$ & 14 & 14 & 27 & 6 & 6 & 2 \\
\hline Ceará & NE & 15 & 15 & 6 & 16 & 5 & 23 \\
\hline Sergipe & NE & 16 & 13 & 10 & 22 & 12 & 20 \\
\hline Rio Grande do Norte & NE & 17 & 12 & 13 & 19 & 4 & 14 \\
\hline Espírito Santo & SE & 18 & 8 & 26 & 8 & 18 & 8 \\
\hline Acre & $\mathrm{N}$ & 19 & 24 & 16 & 18 & 16 & 16 \\
\hline Bahia & $\mathrm{NE}$ & 20 & 7 & 5 & 24 & 17 & 24 \\
\hline Paraíba & $\mathrm{NE}$ & 21 & 20 & 9 & 25 & 9 & 21 \\
\hline Piauí & $\mathrm{NE}$ & 22 & 16 & 15 & 21 & 10 & 26 \\
\hline Amazonas & $\mathrm{N}$ & 23 & 5 & 11 & 23 & 27 & 17 \\
\hline Maranhão & $\mathrm{NE}$ & 24 & 19 & 8 & 20 & 26 & 27 \\
\hline Amapá & $\mathrm{N}$ & 25 & 23 & 23 & 13 & 22 & 15 \\
\hline Alagoas & $\mathrm{NE}$ & 26 & 26 & 22 & 27 & 25 & 25 \\
\hline Permanbuco & $\mathrm{NE}$ & 27 & 25 & 25 & 26 & 23 & 18 \\
\hline \multicolumn{2}{|l|}{ correlation with YWI } & & 0.30 & 0.22 & 0.81 & 0.55 & 0.68 \\
\hline
\end{tabular}

* CW=Center West, CE = Center East, $\mathrm{NE}=$ Northeast, $\mathrm{N}=$ North, $\mathrm{S}=$ South 
Table 4: Ranking of Each State by score on the YWI, C-YWI, and GYWI

\begin{tabular}{|c|c|c|c|}
\hline & YWI & C-YWI & GYWI \\
\hline Federal District & 1 & 1 & 1 \\
\hline Santa Catarina & 2 & 2 & 2 \\
\hline Goiás & 3 & 5 & 6 \\
\hline São Paulo & 4 & 3 & 3 \\
\hline Minas Gerais & 5 & 4 & 4 \\
\hline Rio Grande do Sul & 6 & 10 & 8 \\
\hline Tocantins & 7 & 15 & 16 \\
\hline Roraima & 8 & 8 & 12 \\
\hline Rondônia & 9 & 13 & 13 \\
\hline Mato Grosso & 10 & 12 & 10 \\
\hline Mato Grosso do Sul & 11 & 9 & 9 \\
\hline Paraná & 12 & 7 & 7 \\
\hline Pará & 13 & 16 & 17 \\
\hline Rio de Janeiro & 14 & 6 & 5 \\
\hline Ceará & 15 & 11 & 14 \\
\hline Sergipe & 16 & 18 & 18 \\
\hline Rio Grande do Norte & 17 & 17 & 15 \\
\hline Espírito Santo & 18 & 14 & 11 \\
\hline Acre & 19 & 22 & 19 \\
\hline Bahia & 20 & 20 & 20 \\
\hline Paraíba & 21 & 21 & 22 \\
\hline Piauí & 22 & 19 & 23 \\
\hline Amazonas & 23 & 23 & 24 \\
\hline Maranhão & 24 & 25 & 25 \\
\hline Amapá & 25 & 24 & 21 \\
\hline Alagoas & 26 & 27 & 27 \\
\hline Pernambuco & 27 & 26 & 26 \\
\hline
\end{tabular}


Figure 1: Brazilian Youth Well-Being Index, by State

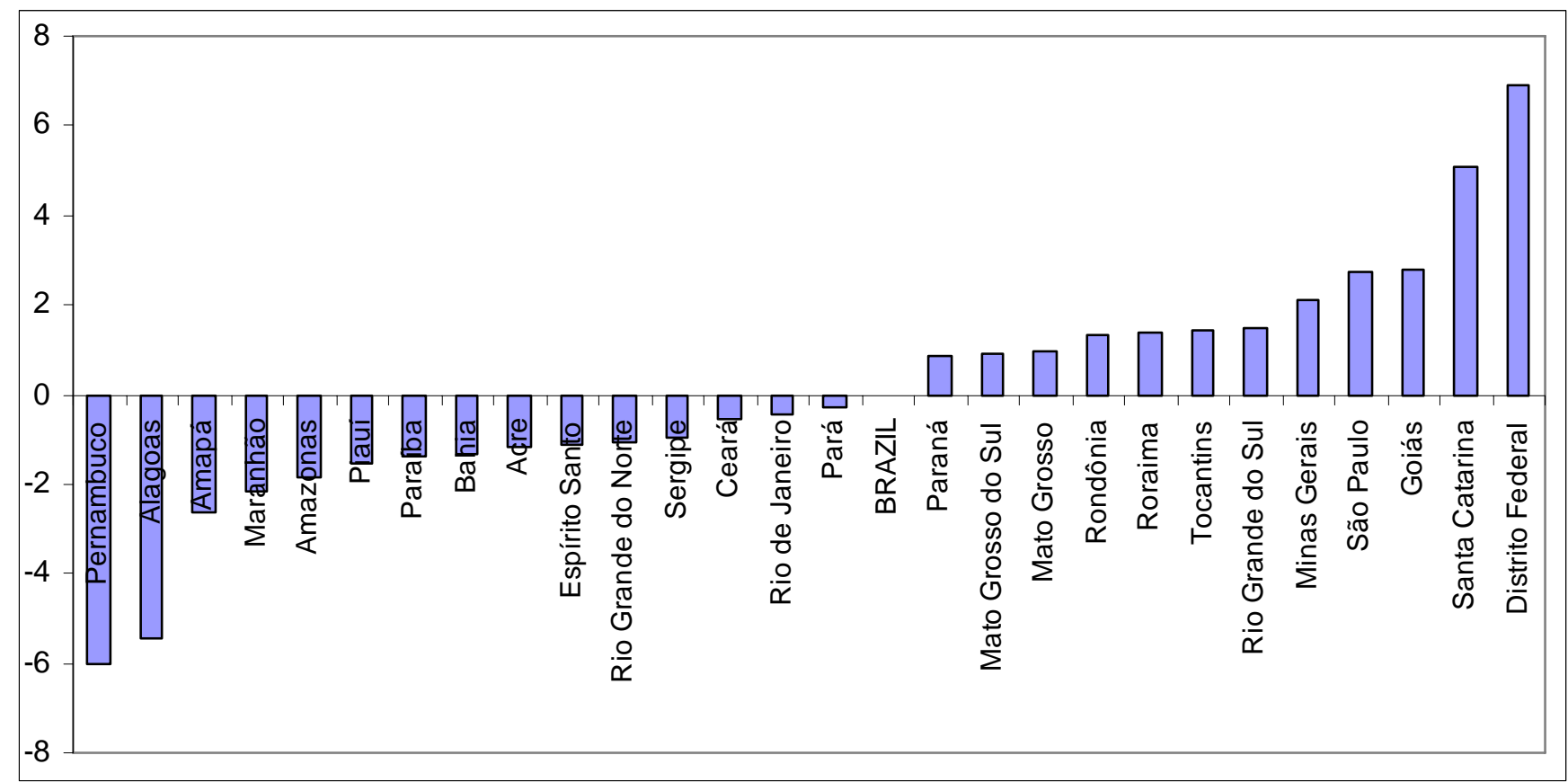

Figure 2: Deviation from the base (100) of the YWI and the standardized score from the health category (used to create the YWI)

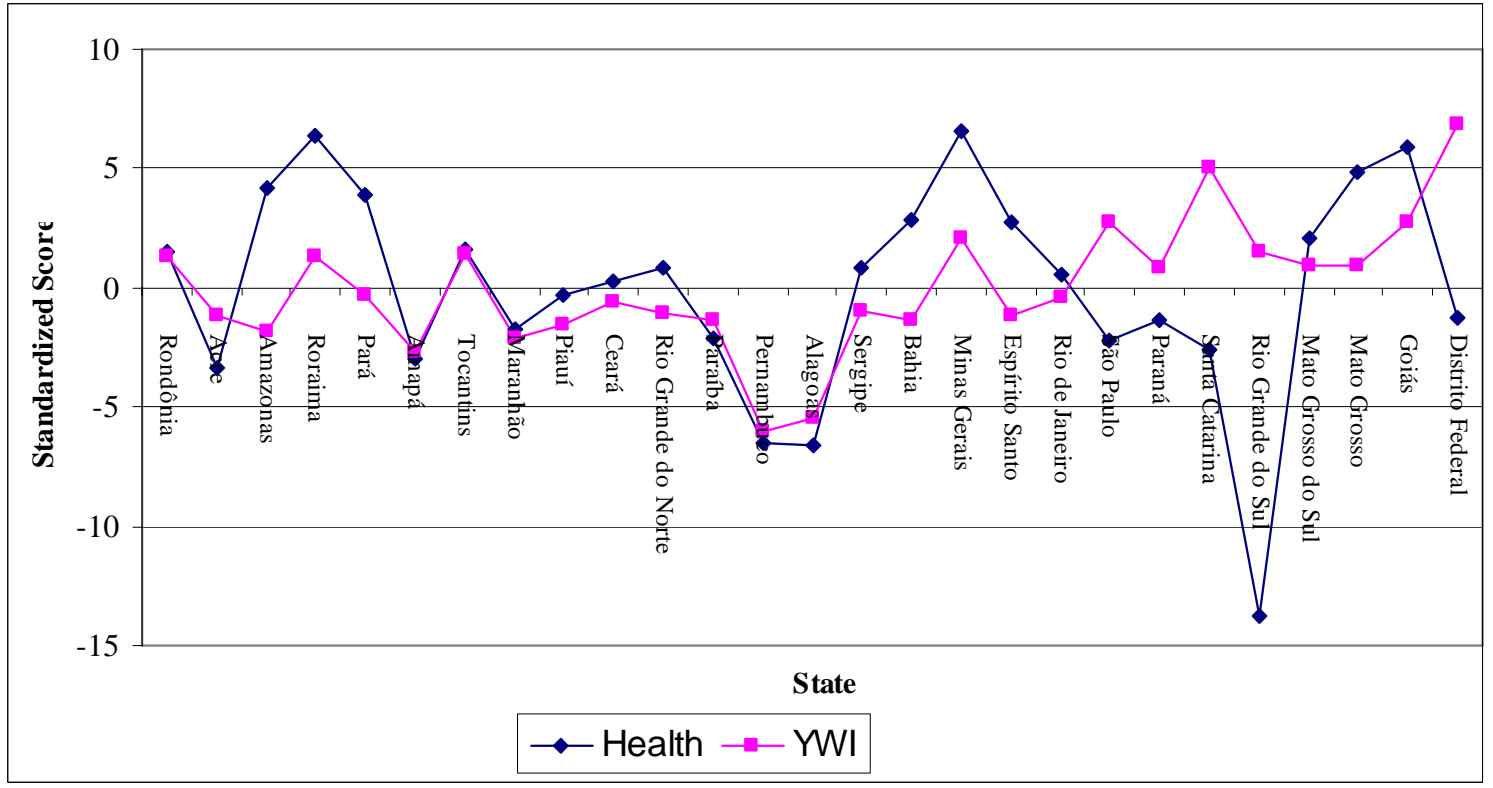


Figure 3: Deviation from the base (of 100) of the YWI and the standardized score from the behavior category (used to create the YWI)

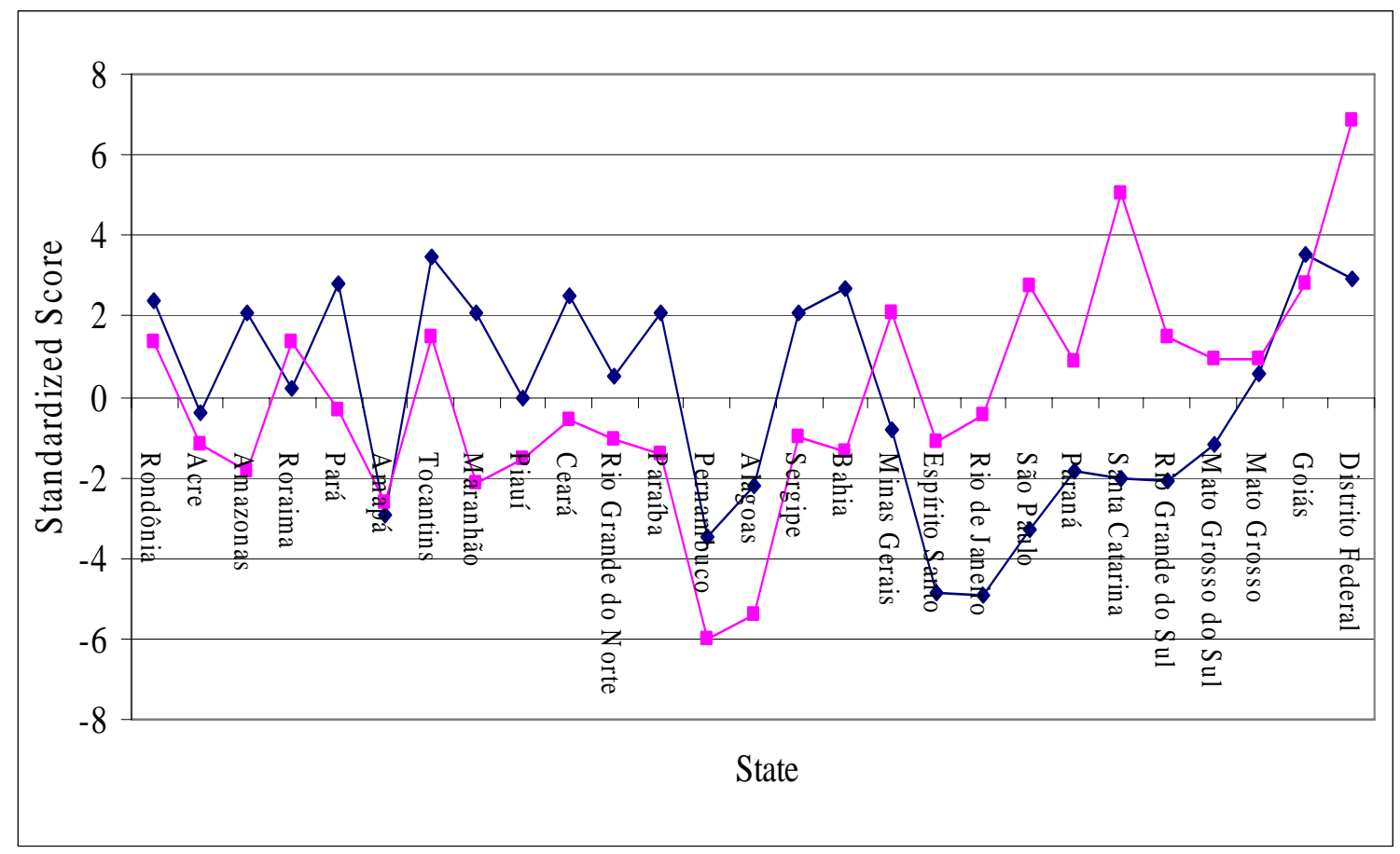

Figure 4: YWI, C-YWI, and GWI by state: 2002

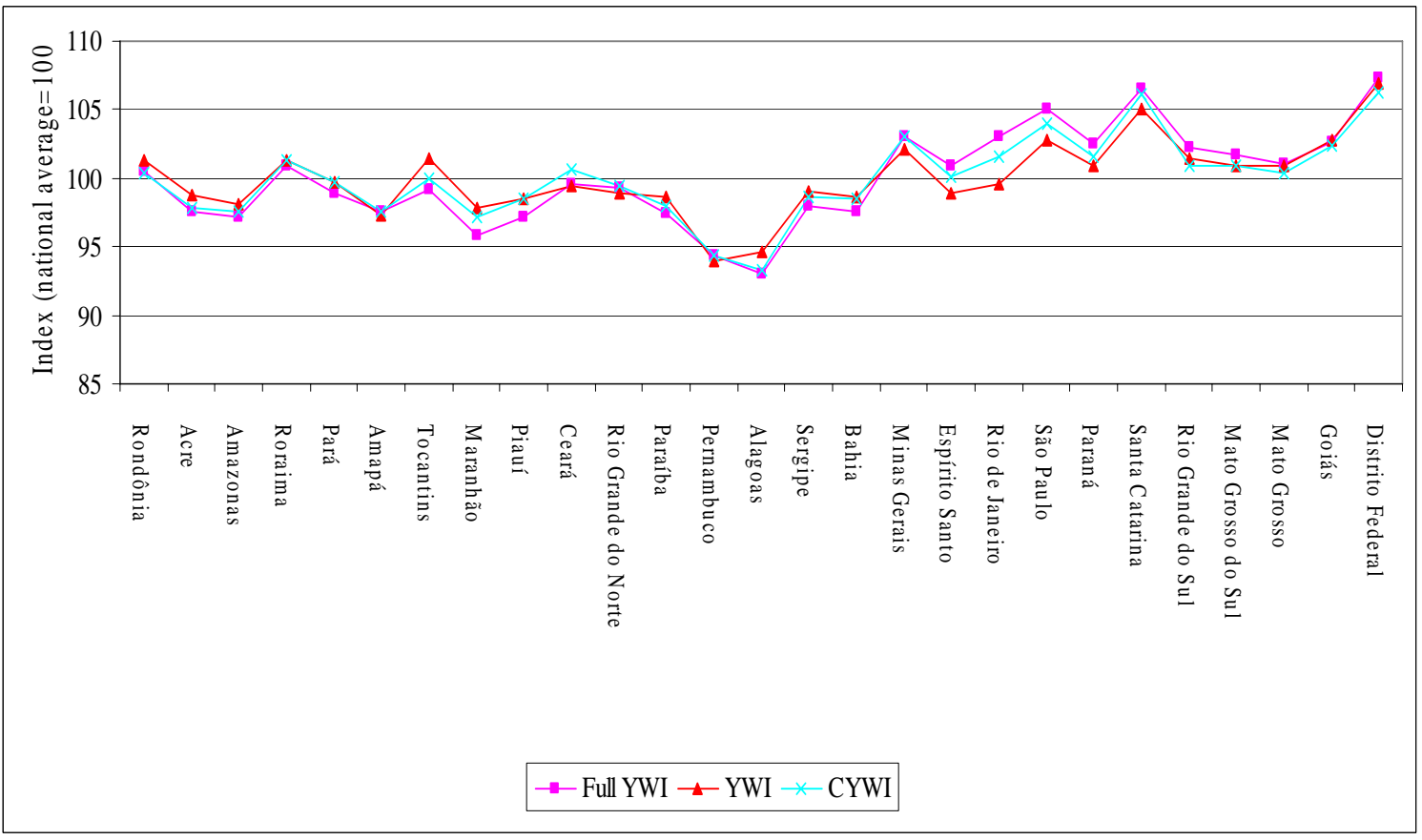


Figure 5: General Youth Well-Being Index, by State

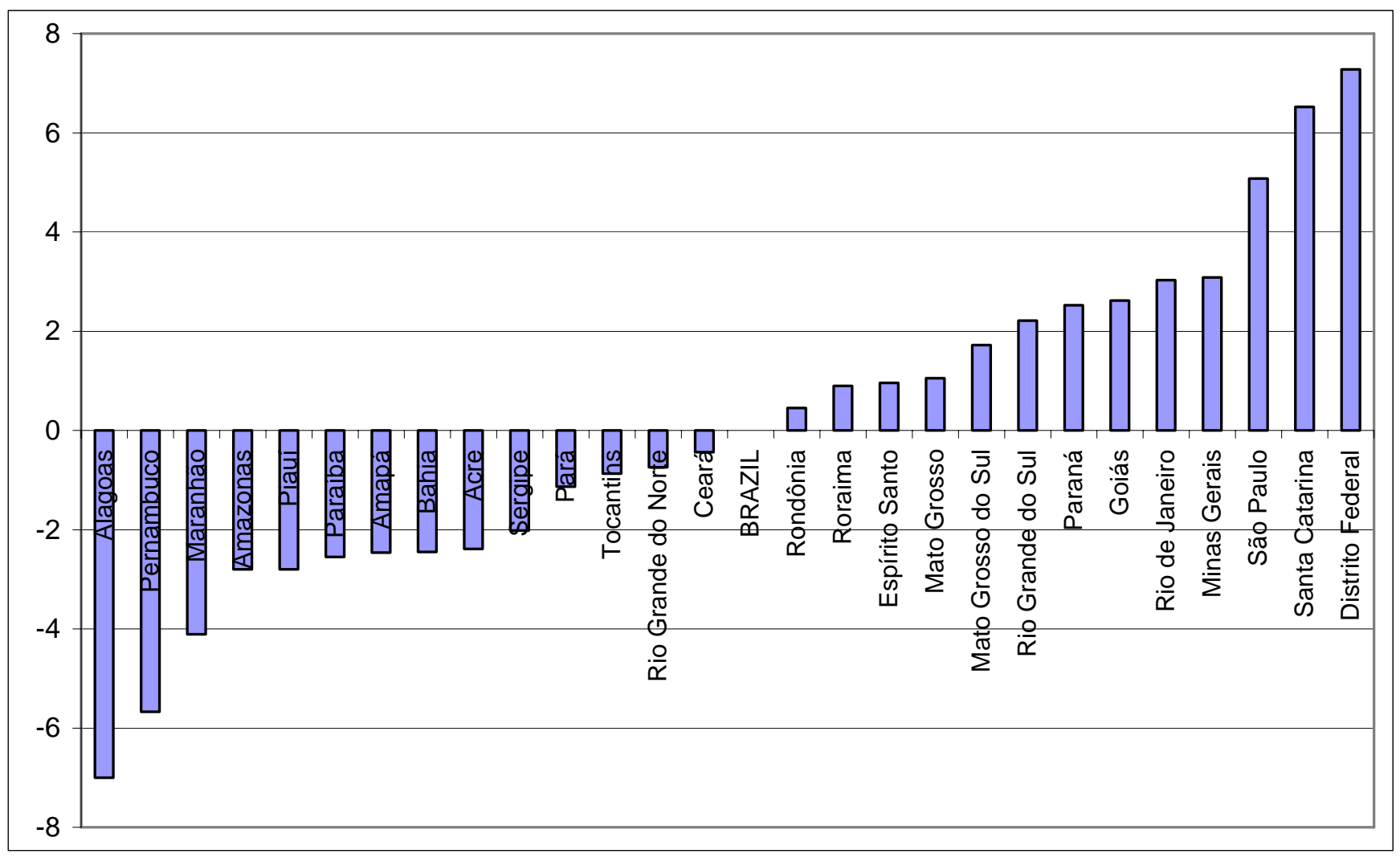

Figure 6: Deviation from the base (of 100) of the YWI and the standardized score from the Socioeconomic variables (used to create the FYWI)

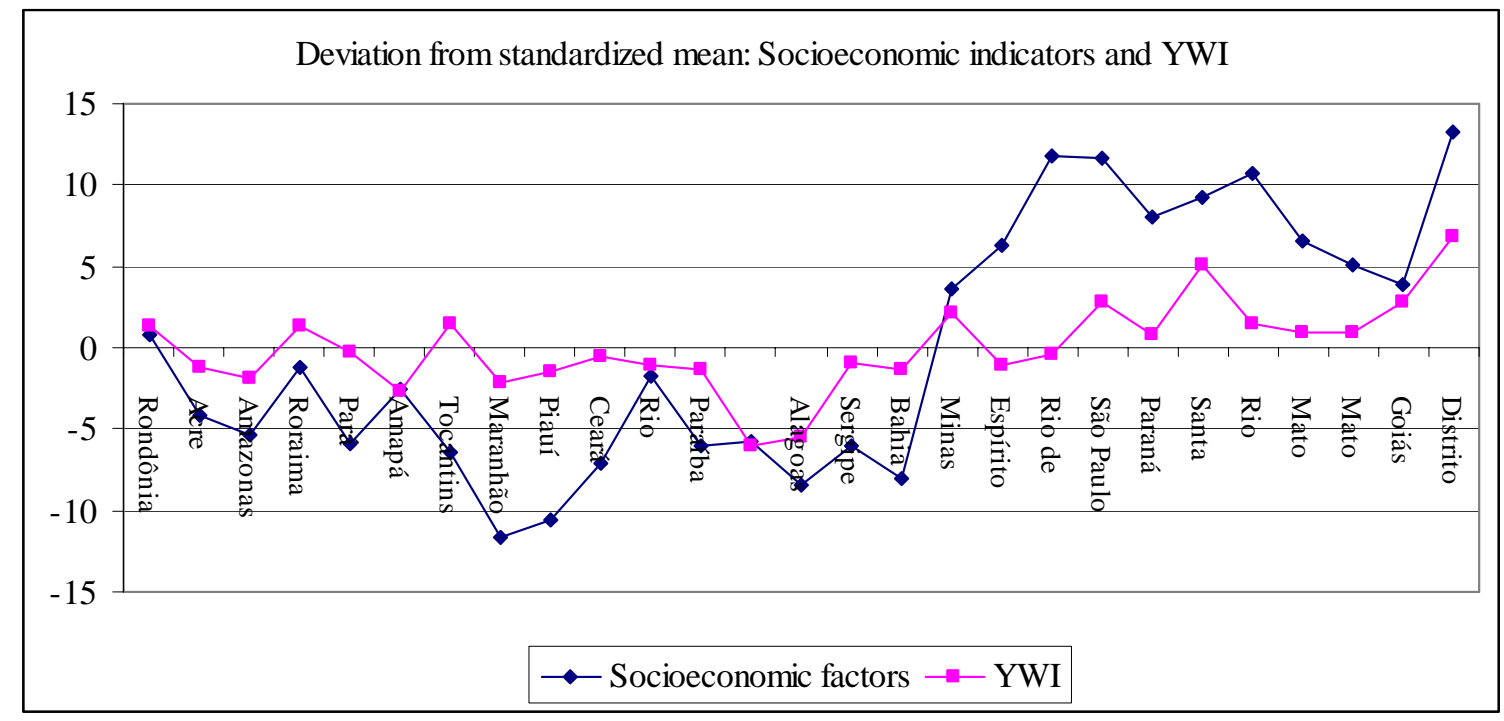




\section{References}

Abramovay, M. and M. Rua (2002) Violencia nas Escolas. (UNESCO: Brasília).

Abramovay, M. et. al. (2003) Escolas Innovadoras: Experiencias Bem-Sucedidas em Escolas Públicas. (UNESCO: Brasília).

Blom, Andreas, et al. (2001) "Education, Earnings, and Inequality in Brazil 1982-1998." (The World Bank: Washington, DC).

Blum, R., C.A. McNeely, and P.M. Rinehart (2002) Improving the Odds: The Untapped Power of Schools to Improve the Health of Teens. (Center for Adolescent Health and Development, University of Minnesota: Minneapolis, MN).

Blum, R., C.A. McNeely, and P.M. Rinehart (2002) Improving the Odds: The Untapped Power of Schools to Improve the Health of Teens. (Center for Adolescent Health and Development, University of Minnesota: Minneapolis, MN).

Bonelli, Regis and Alinne Veiga (2004) "Determinants of Educational Exclusion in Five States of Brazil" in Maria-Valeria Pena and Maria Madalena dos Santos (eds) Children's and Youth Vulnerability: Poverty, Exclusion and Social Risk in Five Brazilian States (The World Bank: Brasília).

Bonelli, Regis, Jose Guilherme Reis, and Alinne Veiga (2004) "Characteristics and Determinants of Youth Unemployment in Brazil," LCSES/World Bank, mimeo.

Bronfenbrenner, U. (1979) The ecology of human development. (Harvard University Press: Cambridge, MA).

Carlini, E.A., Galduróz, J. C. F., Noto, A. R., Nappo, S. A. (2002). I Levantamento sobre o Uso de Drogas Psicotrópicas no Brasil - 2001. (São Paulo: CEBRID - Centro Brasileiro de Informações sobre Drogas Psicotrópicas: UNIFESP - Universidade Federal de São Paulo).

Cummins (1996) “The Domains of Life Satisfaction: An Attempt to Order Chaos" Social Indicators Research (38), 303-328.

Duke University (2004) Child Well-Being Index ( www.soc.duke.edu/ cwi)

Human Rights Watch (2003) Fact Sheet: Juvenile Detention in Brazil, April 2003

Instituto Cidadania (2004) Projecto Juventude: Documento de Conclusão (Brasilia, Brazil)

Koller, Silvia, J'amis Ribeiro, Elder Cerqueira-Santoa, Normanda Araujo de Morais, and Maycoln Leoni Teodoro (2005) "Juventude Brasileira: Comportamentos de Risco, Fatores de Risco e de Proteção.” Mimeo. 
Koller, Silvia (ed.), 2004. Ecologia do Desenvolvimento Humano: Pesquisa e Intervencao no Brasil (Casa do Psicologo Livraria e Editora Ltds: Brazil).

Lloyd, Cynthia (2005) Growing Up Global: The Changing Transitions to Adulthood in Developing Countries. Panel on Transitions to Adulthood in Developing Countries. (National Research Council: Washington, DC).

NAP/Brazilian Ministry of Health (November 2006) "Epidemiological Surveillance Bulletin".

Rodríguez, Alberto and Carlos A. Herrán (2000) "Secondary Education in Brazil: Time to Move Forward.” (World Bank and Inter-American Development Bank: Washington, DC).

Schweinhart, Lawrence (2004). "The High/Scope Perry Preschool Study through Age 40: Summary, Conclusions, and Frequently Asked Questions.” (High/Scope Press: Ypsilanti, Mich.)

Soares, Sergei, Luiza Carvalho, Bernardo Kipnis (2003) "Os Jovens Adultos de 18 a 25 Anos: Retrato de Uma Dívida da Política Educacional." IPEA Texto para Discussao No. 954. (IPEA: Rio de Janeiro).

UNESCO (2002) Mapa da Violência IV: Os Jovens do Brasil (SIM/DATASUS: IBGE).

UNICEF (2002) A Voz dos Adolescentes. (UNICEF: Brasília).

Waiselfisz, J. et. al. (2004) Relatorio de Desenvolvimento Juvenil 2003. (UNESCO: Brasília).

Waiselfisz, J. (2004) Mapa da violencia IV: os jovens do Brasil: juventude, violencia e cidadania. (UNESCO: Brasília).

Weiss, Zezé (2004) Vozes Jovens. (The World Bank: Brasília).

World Bank (2000) "Youth and Social Development: An Integrated Approach for Social Inclusion.” (The World Bank: Washington, DC)

World Bank (2003) Youth Development in the Caribbean. (The World Bank: Washington, DC).

World Bank (2005) "Youth in Numbers: LAC.” (The World Bank: Washington, DC). 


\section{Annex 1: Health}

\begin{tabular}{|c|c|c|c|c|c|c|c|c|c|c|}
\hline UF & 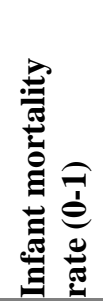 & 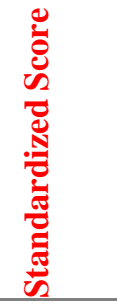 & 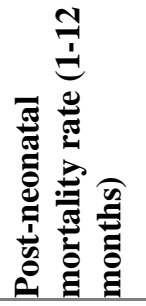 & 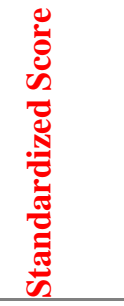 & 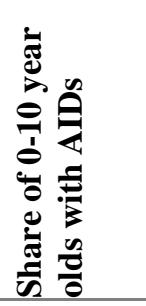 & 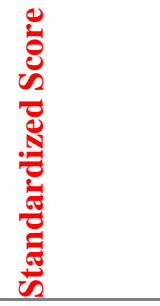 & 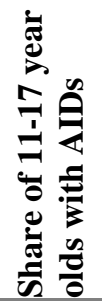 & 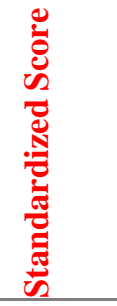 & 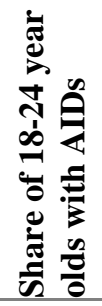 & 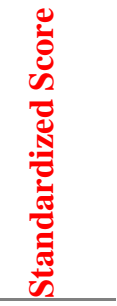 \\
\hline Rondônia & 24.60 & 103.79 & 7.90 & 105.01 & 0.57 & 104.14 & 0.89 & 86.97 & 2.00 & 107.42 \\
\hline Acre & 33.20 & 96.22 & 14.70 & 94.17 & 0.61 & 103.79 & 1.06 & 82.71 & 2.41 & 106.51 \\
\hline Amazonas & 28.80 & 100.09 & 11.10 & 99.91 & 0.12 & 108.42 & 0.21 & 104.20 & 1.66 & 108.20 \\
\hline Roraima & 17.80 & 109.77 & 7.60 & 105.49 & 0 & 109.56 & 0 & 109.54 & 6.37 & 97.53 \\
\hline Pará & 27.30 & 101.41 & 10.10 & 101.51 & 0.47 & 105.13 & 0.19 & 104.73 & 2.31 & 106.72 \\
\hline Amapá & 24.90 & 103.53 & 6.60 & 107.09 & 0.70 & 102.91 & 1.22 & 78.65 & 8.35 & 93.05 \\
\hline Tocantins & 28.40 & 100.45 & 11.40 & 99.43 & 1.01 & 100.04 & 0 & 109.54 & 6.01 & 98.36 \\
\hline Maranhão & 46.30 & 84.70 & 19.40 & 86.68 & 0.19 & 107.70 & 0.09 & 107.10 & 3.07 & 105.00 \\
\hline Piauí & 33.10 & 96.31 & 11.60 & 99.11 & 0.59 & 103.96 & 0.39 & 99.44 & 5.43 & 99.67 \\
\hline Ceará & 35.10 & 94.55 & 14.10 & 95.13 & 0.27 & 106.94 & 0.33 & 101.12 & 3.78 & 103.40 \\
\hline Rio Grande do Norte & 41.90 & 88.57 & 19.00 & 87.32 & 0.16 & 108.05 & 0 & 109.54 & 0.52 & 110.78 \\
\hline Paraíba & 45.50 & 85.40 & 18.90 & 87.48 & 0.91 & 100.99 & 0 & 109.54 & 2.73 & 105.78 \\
\hline Pernambuco & 44.80 & 86.02 & 20.10 & 85.56 & 1.36 & 96.78 & 0.24 & 103.37 & 7.13 & 95.82 \\
\hline Alagoas & 57.70 & 74.66 & 30.70 & 68.66 & 0.27 & 106.96 & 0 & 109.54 & 2.21 & 106.94 \\
\hline Sergipe & 40.60 & 89.71 & 14.70 & 94.17 & 0.69 & 103.00 & 0 & 109.54 & 1.93 & 107.59 \\
\hline Bahia & 38.70 & 91.38 & 13.50 & 96.08 & 0.16 & 107.98 & 0 & 109.54 & 1.28 & 109.05 \\
\hline Minas Gerais & 20.80 & 107.13 & 6.10 & 107.88 & 0.16 & 108.02 & 0.15 & 105.56 & 3.34 & 104.39 \\
\hline Espírito Santo & 20.90 & 107.05 & 6.20 & 107.72 & 1.42 & 96.19 & 0.44 & 98.39 & 3.41 & 104.23 \\
\hline Rio de Janeiro & 19.50 & 108.28 & 5.70 & 108.52 & 0.60 & 103.90 & 0.75 & 90.52 & 9.05 & 91.47 \\
\hline São Paulo & 17.40 & 110.13 & 5.40 & 109.00 & 2.20 & 88.80 & 0.78 & 89.79 & 9.09 & 91.37 \\
\hline Paraná & 20.70 & 107.22 & 6.20 & 107.72 & 1.90 & 91.67 & 0.68 & 92.27 & 7.80 & 94.30 \\
\hline Santa Catarina & 18.20 & 109.42 & 6.50 & 107.25 & 1.37 & 96.60 & 0.53 & 95.92 & 15.11 & 77.77 \\
\hline Rio Grande do Sul & 15.40 & 111.89 & 5.90 & 108.20 & 4.73 & 65.10 & 1.14 & 80.59 & 20.62 & 65.29 \\
\hline Mato Grosso do Sul & 19.20 & 108.54 & 6.00 & 108.04 & 1.94 & 91.26 & 0.32 & 101.26 & 4.61 & 101.52 \\
\hline
\end{tabular}




\begin{tabular}{lrrrrrrrrrr}
\hline Mato Grosso & 21.50 & 106.52 & 6.50 & 107.25 & 1.04 & 99.79 & 0 & 109.54 & 4.73 & 101.25 \\
Goiás & 20.70 & 107.22 & 7.10 & 106.29 & 0.65 & 103.39 & 0 & 109.54 & 4.04 & 102.82 \\
Distrito Federal & 17.50 & 110.04 & 5.20 & 109.32 & 3.26 & 78.92 & 0.71 & 91.57 & 3.61 & 103.78 \\
& & & & & & & \\
National Average & 28.91 & 100.00 & 11.04 & 100.00 & 1.02 & 100.00 & 0.38 & 100.00 & 5.29 & 100.00 \\
Standard Error & 11.36 & 10.00 & 6.27 & 10.00 & 1.06 & 10.00 & 0.40 & 10.00 & 4.42 & 10.00 \\
\hline
\end{tabular}


Annex 2: Behaviors

\begin{tabular}{|c|c|c|c|c|c|c|c|c|c|c|c|c|c|c|c|c|}
\hline UF & 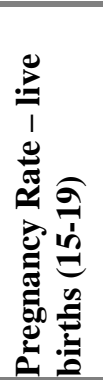 & 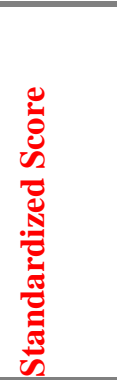 & 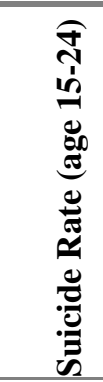 & 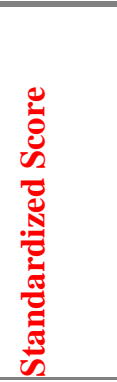 & 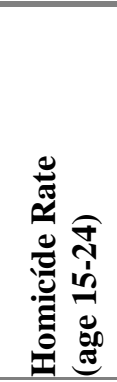 & 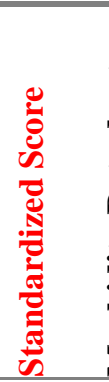 & 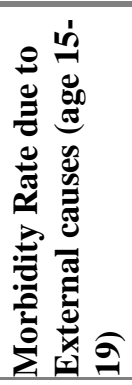 & 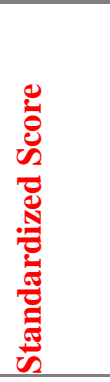 & 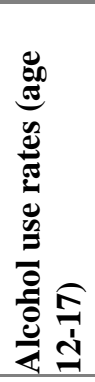 & 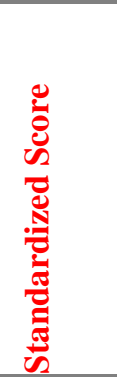 & 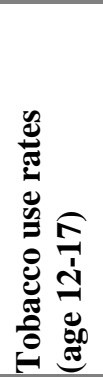 & 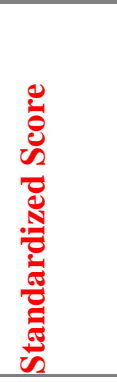 & 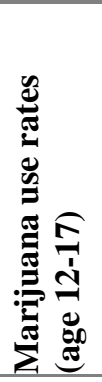 & 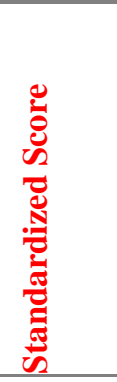 & 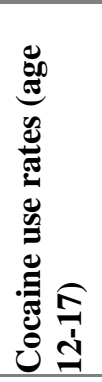 & 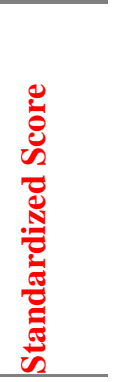 \\
\hline Rondé & 25.40 & 87.03 & 4.90 & 102.90 & 57.00 & 97.54 & 0.60 & 117.68 & 25.50 & 113.56 & 14.50 & 99.94 & 4.00 & 92.35 & 0.00 & 108.2 \\
\hline 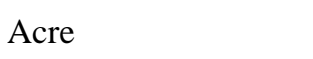 & 90 & $85 ? 2$ & 6.20 & & 52.30 & 99.17 & 2.10 & & 5.50 & 113 & 4.50 & 94 & 4.00 & & .00 & 3.24 \\
\hline $\mathrm{ma}$ & .50 & 97.46 & 5.50 & 101.04 & 33.10 & 105.85 & 2.21 & 98.20 & 25.50 & 113.56 & 14.50 & 99.94 & 4.00 & 35 & 0.00 & 108.24 \\
\hline Rorain & .80 & 96.38 & 14.70 & 72.62 & 68.20 & 93.64 & 0.00 & 124.93 & 25.50 & 113.56 & 14.50 & 94 & 4.00 & 92.35 & 0.00 & 108.24 \\
\hline & .30 & 87.39 & 4.00 & 105. & 29.80 & 107.00 & 1.37 & & 25.50 & 113.56 & 14.50 & 99.94 & 4. & 92.35 & .00 & 108.24 \\
\hline á & .90 & 96.02 & 13.80 & 75.40 & 81.20 & 89.12 & 1.91 & 101.83 & 25.50 & 113.56 & 14.50 & 99.94 & 4.00 & 92.35 & 0.00 & 108.24 \\
\hline & .80 & 81.99 & 3.50 & 107.22 & 21.50 & 109.89 & 0.86 & 114.53 & 25.50 & 113.56 & 14.50 & 99.94 & 4.00 & 92.35 & 0.00 & 108.24 \\
\hline ara & 80 & 92.78 & 2.90 & 109.07 & 15.00 & 112.15 & 1.79 & 103.28 & 45.80 & & 14.30 & 100.71 & 2.40 & 103.37 & 0.50 & 99.88 \\
\hline auí & .80 & 2.78 & 50 & 101. & 19.90 & 110. & 2.41 & 95.78 & 45.80 & 9 & 14.30 & 100 & 2.40 & 7 & .5 & 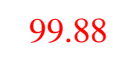 \\
\hline ré & 70 & 7.53 & .40 & 98 & 31.00 & 106.58 & 1.40 & 108.00 & 45.80 & 59 & 14.30 & 100.71 & 2.40 & & .50 & 99.88 \\
\hline io & 21.90 & 99.61 & 4.30 & 104.75 & 16.90 & 111.49 & 2.99 & 88.77 & 45.80 & & 14.30 & & 2.40 & & 0.5 & \\
\hline & .70 & 100.33 & .20 & & 32.00 & 106.23 & & & 45.80 & & 14.30 & & 2.40 & & 0 & \\
\hline Perl & .30 & 1.77 & 3.70 & 106.60 & 103.40 & 81.39 & 3.47 & 82.96 & 45.80 & 59 & 14.30 & 100.71 & 2.40 & 10 & .50 & 99.88 \\
\hline Alagoas & .90 & 99.61 & 4.70 & 103.51 & 62.20 & 95.73 & 3.38 & 84.05 & 45.80 & 95.59 & 14.30 & 100.71 & 2.40 & 103.37 & 0.50 & 99.88 \\
\hline ergipe & .60 & 104.29 & 4.30 & 104.75 & 53.70 & 98.68 & 1.28 & 109.45 & 45.80 & & 14.30 & 100.71 & 2.40 & 103.37 & 0.50 & 99.88 \\
\hline Ballid & .40 & & 1.90 & & 23.10 & 109.33 & 1.5 & 106 & 45.80 & & 14.30 & & 2.40 & & 0.50 & \\
\hline Minas & 18.00 & 113.64 & 4.70 & 103.51 & 30.70 & 106.69 & 2.15 & 98.93 & 53.70 & 88.60 & 16.80 & 91.16 & 4.40 & 89.59 & 0.40 & 101.55 \\
\hline & .10 & 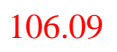 & 3.80 & 106.29 & 3.70 & 81.29 & 2.36 & 96.39 & 53.70 & 50 & 16.80 & & 4.40 & & .40 & 101.55 \\
\hline Nou & .30 & & 2.90 & 109.07 & 118.90 & 76.00 & 2.7 & 92.16 & 53.70 & & 16.80 & & 4.40 & & 0.40 & 101.55 \\
\hline São Paulo & 7.60 & 15.08 & 4.10 & 105.37 & 81.00 & 89.19 & 2.61 & 93.37 & 53.70 & 88.60 & 16.80 & 91.16 & 4.40 & 89.59 & 0.40 & 101.55 \\
\hline Paraná & 20.00 & 106.45 & 6.30 & 98.57 & 45.50 & 101.54 & 1.77 & 103.53 & 54.50 & 87.89 & 18.70 & 83.91 & 3.60 & 95.10 & 0.00 & 108.24 \\
\hline Santa Catarina & 18.80 & 110.76 & 7.10 & 96.10 & 16.80 & 111.52 & 2.86 & 90.34 & 54.50 & 87.89 & 18.70 & 83.91 & 3.60 & 95.10 & 0.00 & 108.24 \\
\hline
\end{tabular}




\begin{tabular}{lrrrrrrrrrrrrrrrr}
\hline Rio Grande do Sul & 18.10 & 113.28 & 7.80 & 93.93 & 35.60 & 104.98 & 2.38 & 96.15 & 54.50 & 87.89 & 18.70 & 83.91 & 3.60 & 95.10 & 0.00 & 108.24 \\
Mato Grosso do Sul & 24.10 & 91.70 & 12.70 & 78.79 & 48.90 & 100.35 & 2.43 & 95.54 & 33.30 & 106.66 & 9.40 & 119.41 & 0.00 & 119.89 & 1.80 & 78.14 \\
Mato Grosso & 24.50 & 90.26 & 6.60 & 97.64 & 51.40 & 99.48 & 2.62 & 93.24 & 33.30 & 106.66 & 9.40 & 119.41 & 0.00 & 119.89 & 1.80 & 78.14 \\
Goiás & 22.70 & 96.74 & 7.10 & 96.10 & 40.90 & 103.14 & 1.40 & 108.00 & 33.30 & 106.66 & 9.40 & 119.41 & 0.00 & 119.89 & 1.80 & 78.14 \\
Distrito Federal & 16.50 & 119.03 & 6.00 & 99.50 & 74.10 & 91.59 & 2.95 & 89.25 & 33.30 & 106.66 & 9.40 & 119.41 & 0.00 & 119.89 & 1.80 & 78.14 \\
& & & & & & & & & & & & & & & & \\
National Average & 21.79 & 100.00 & 5.84 & 100.00 & 49.92 & 100.00 & 2.06 & 100.00 & 40.82 & 100.00 & 14.49 & 100.00 & 2.89 & 100.00 & 0.49 & 100.00 \\
Standard Deviation & 2.78 & 10.00 & 3.24 & 10.00 & 28.74 & 10.00 & 0.83 & 10.00 & 11.30 & 10.00 & 2.62 & 10.00 & 1.45 & 10.00 & 0.60 & 10.00 \\
\hline
\end{tabular}


Annex 3: School Performance

\begin{tabular}{|c|c|c|c|c|c|c|c|c|c|c|c|c|c|c|c|c|c|c|}
\hline $\mathbf{F}$ & 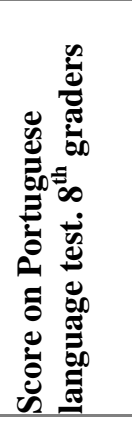 & 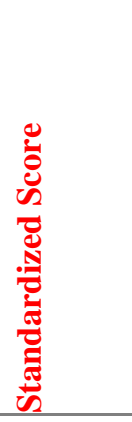 & 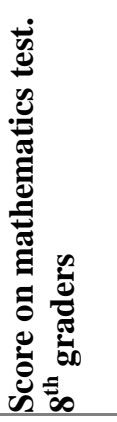 & 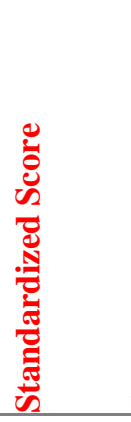 & 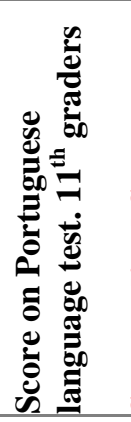 & 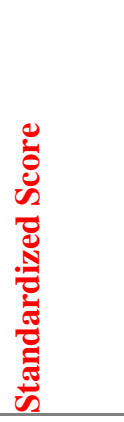 & 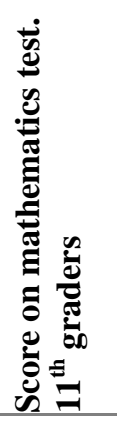 & 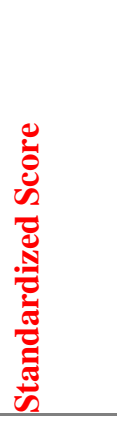 & 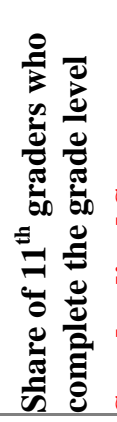 & 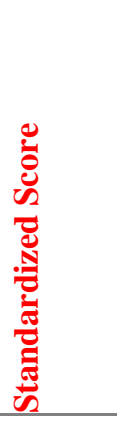 & 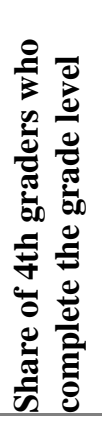 & 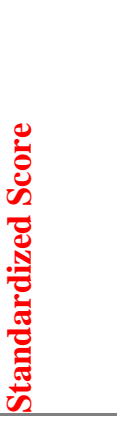 & 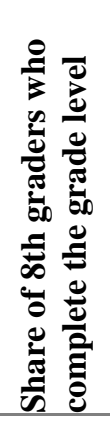 & 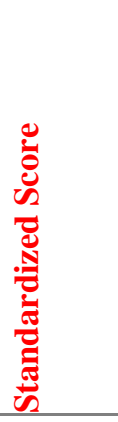 & 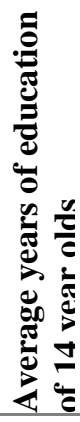 & 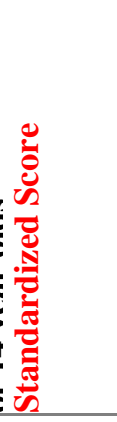 & 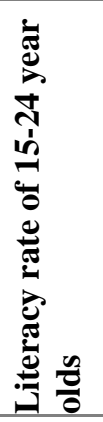 & 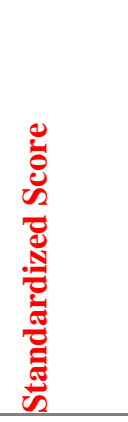 \\
\hline ondônia & 237.40 & 104.76 & 240.70 & 101.57 & 260.70 & 102.57 & 275.20 & 102.64 & 44.30 & 99.55 & 82.20 & 104.46 & 76.30 & 99.94 & 5.40 & 102.67 & 98.80 & ) 107.91 \\
\hline Acre & 222.50 & 90.56 & 223.10 & 86.36 & 247.00 & 92.24 & 258.40 & 91.48 & 75.90 & 102.86 & 72.40 & 92.34 & 81.30 & 107 & 5.30 & 101.28 & 94.30 & 96.93 \\
\hline $\mathrm{m}$ & 221.20 & 89.32 & 26.30 & 89.13 & 240.80 & 87.57 & 243.80 & 78 & 72.30 & 41 & 71.50 & 22 & 72.80 & & 4.90 & 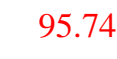 & 98.60 & 10 \\
\hline Ror & 229.40 & 97.14 & 34.60 & 96.30 & 240.60 & 87.42 & 253.00 & 89 & 74.10 & 99.13 & 82.60 & 104.96 & 85.00 & 113 & 5.50 & 10 & 97.90 & 10 \\
\hline ará & 235.70 & 103.14 & 235.50 & 97.08 & 253.10 & 96.84 & 259.30 & 08 & B 70.50 & 91.69 & 67.30 & 86.03 & 77.10 & 10 & 4.60 & 59 & 96.40 & 10 \\
\hline Amap & 232.50 & 100.09 & 231.80 & 93.88 & 252.50 & 96.39 & 255.60 & 89.62 & 74.70 & 100.38 & 76.40 & 97.29 & 81.40 & 10 & 5.40 & 102.67 & 99.30 & 109.13 \\
\hline To & 227.90 & 95.71 & 32.30 & 94.31 & 237.40 & 85.00 & 255.00 & 89 & 277.40 & 105 & 79.30 & 100.88 & 82.90 & 10 & 4.90 & 95.74 & 96.30 & 10 \\
\hline Marar & 5.60 & 83 & 3.10 & 86.36 & 246.10 & 91.56 & 257.10 & 90 & 82.10 & 1 & 76.50 & 97.41 & 78.20 & 10 & 4.40 & 32 & 91.00 & \\
\hline Piauí & 228.90 & 96.66 & 239.60 & 100.62 & 258.80 & 101.14 & 270.70 & 99.65 & 75.50 & 102.03 & 70.90 & 90.48 & 373.30 & & 3.80 & 51 & 87.20 & 79.59 \\
\hline Ceará & 219.60 & 87.80 & 226.20 & 89.04 & 254.00 & 97.52 & 266.70 & 96.99 & 77.40 & 105.96 & 82.20 & 104.46 & 78.40 & 103 & 4.90 & 4 & 92.70 & 93 \\
\hline Rio & 228.20 & 95.99 & 33.70 & 95.52 & 245.10 & 90.81 & 259.10 & 91 & 75.90 & 102.86 & 73.90 & 94.19 & 70.70 & 9 & 4.90 & 95.74 & 90.90 & 88 \\
\hline Paraíba & 224.60 & 92.56 & 2.00 & 5 & 244.10 & 0.06 & 265.90 & 9 & 75.30 & 101.62 & 70.30 & 89 & +69.90 & 9 & 4.20 & 86.05 & 88.80 & 83.50 \\
\hline Pern & 217.80 & 86.08 & 6.00 & 88.87 & 245.00 & 90.73 & 260.40 & 92.81 & 75.10 & 101.20 & 73.10 & 93.20 & 69.10 & 89.05 & 4.60 & 1.59 & 91.40 & 89.85 \\
\hline Alagoas & 216.60 & 84.94 & 225.50 & 88.43 & 246.70 & 92.02 & 261.30 & 93.40 & 71.10 & 92.93 & 67.80 & 86.65 & 68.00 & 87.38 & 4.00 & 83.28 & 85.30 & 74.95 \\
\hline Ser६ & 226.50 & 94.37 & 31.60 & 93.71 & 248.20 & 93.15 & 267.00 & 97.19 & 74.10 & 99.13 & 65.50 & 83.80 & 68.40 & 87 & 4.40 & 88.82 & 93.30 & 94 \\
\hline ahia & 225.90 & 93.80 & 232.30 & 94.31 & 250.00 & 94.50 & 267.60 & 97.59 & 71.40 & 93.55 & 66.10 & 84.54 & 64.00 & 81 & 4.50 & 90.20 & 94.20 & 96.68 \\
\hline Min & 242.50 & 109.62 & 254.90 & 113.85 & 266.50 & 106.94 & 280.30 & 106.03 & 33.30 & 97.48 & 89.00 & 112.88 & 83.60 & 110 & 5.80 & 108.21 & 97.70 & 105.23 \\
\hline Espír & 240.60 & 107.81 & 246.40 & 106.50 & 265.80 & 106.42 & 280.50 & 106.16 & 69.10 & 88.79 & 84.40 & 107.19 & 79.20 & 104.33 & 5.70 & 106.82 & 98.60 & 107.42 \\
\hline & 247.40 & 114.29 & & 110.91 & 272.50 & & 280.90 & & 72.20 & 95.20 & 86.10 & 109.29 & 76.70 & & 5.70 & & 98.70 & 107.67 \\
\hline & 7.20 & 104.57 & .10 & 107.10 & 266.10 & 106.64 & 279.90 & 105.76 & 84.20 & 120 & 94.50 & 119.68 & 390.60 & 12 & 6.30 & 115.13 & 98.80 & 107.91 \\
\hline Paraná & 240.50 & 107.72 & 7.40 & 107.36 & 260.50 & 102.42 & 280.00 & 105.83 & 72.70 & 96.24 & 88.60 & 112.38 & 81.10 & 107.20 & 6.20 & 113.75 & 98.70 & 107.67 \\
\hline
\end{tabular}


Santa Catarina

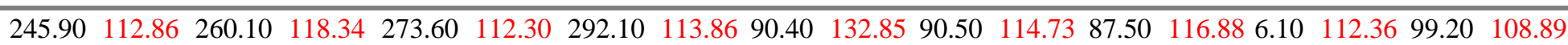

$\begin{array}{llllllll}90.65 & 87.00 & 110.40 & 78.00 & 102.51 & 6.00 & 110.98 & 98.80\end{array}$

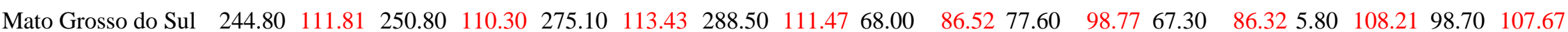

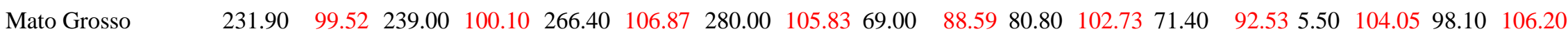

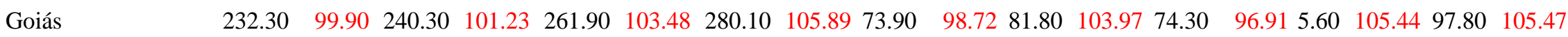

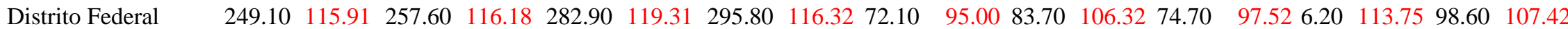

National Average

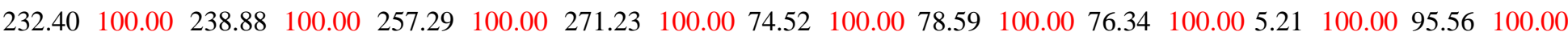

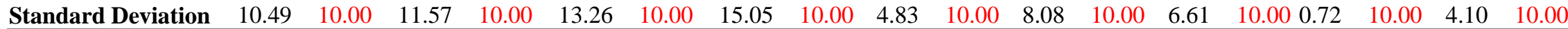




\begin{tabular}{|c|c|c|c|c|c|c|c|c|c|c|c|c|c|c|c|c|c|c|}
\hline UF & 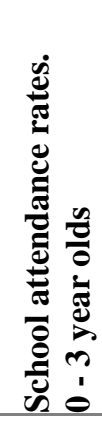 & 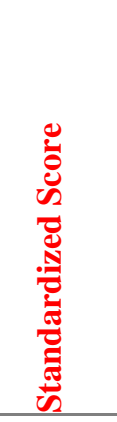 & 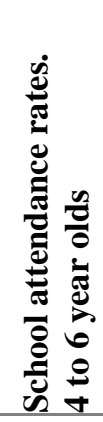 & 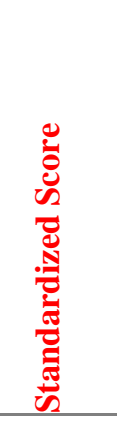 & 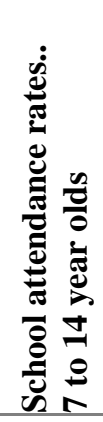 & 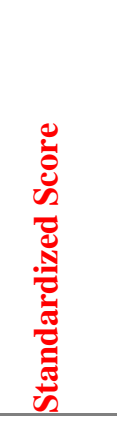 & 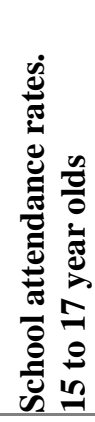 & 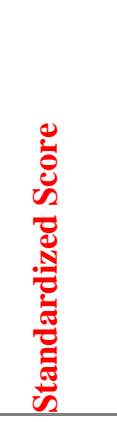 & 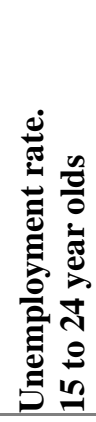 & 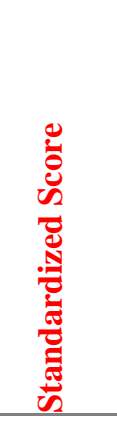 & 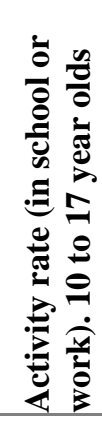 & 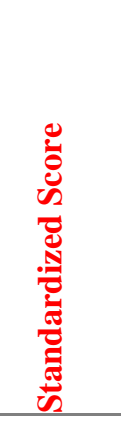 & 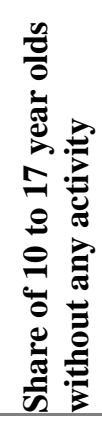 & 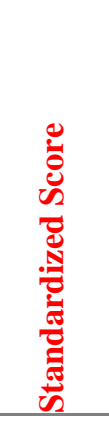 & 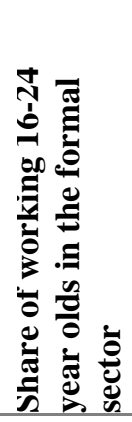 & 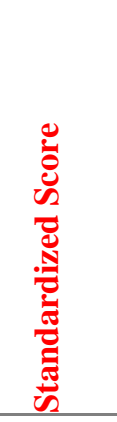 & 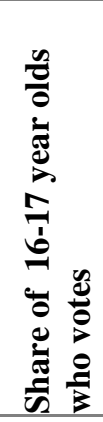 & 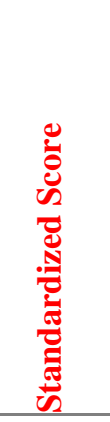 \\
\hline Rond & 4.80 & 86.50 & 49.00 & 82.58 & 95.10 & 93.29 & 75.90 & 87.57 & 12.90 & 106.32 & 19.00 & 100.69 & 1.80 & 101.25 & $5 \quad 13.40$ & 97.87 & 41.40 & 103.18 \\
\hline Acre & 3.70 & 83.78 & 61.60 & 96.67 & 95.50 & 95.87 & 80.80 & 100.66 & 11.90 & 107.93 & 19.40 & 100.11 & 1.80 & 101.25 & 8.50 & 92.56 & 52.93 & 113.95 \\
\hline mind? & 7.20 & 92.43 & 7.10 & 91.64 & 94.00 & 86.19 & 5.00 & 1.88 & 25.30 & 86.36 & 10.70 & 112.73 & 2.40 & 90.60 & 8.91 & 93.01 & 28.80 & 91.40 \\
\hline ora & 15.60 & 113.19 & 8.50 & 93.20 & 91.50 & 70.07 & 82.60 & 105.47 & 8.10 & 114.04 & 6.00 & 119.54 & 2.80 & 83.50 & 8.88 & 92.97 & 56.78 & 117.54 \\
\hline 'aré & 9.80 & 98.86 & 70.30 & 106.40 & 95.70 & 97.16 & 80.30 & 99.33 & 20.00 & 94.89 & 17.00 & 103.59 & 1.60 & 104.80 & 6.88 & 90.80 & 26.72 & 89.46 \\
\hline maná & 5.10 & 87.24 & 1.10 & 96.11 & 95.10 & 93.29 & 87.60 & 118.83 & 35.40 & 70.11 & 7.00 & 118.09 & 3.10 & 78.18 & 7.96 & 91.97 & 50.16 & 111.35 \\
\hline & 3.00 & 82.05 & 52.00 & 85.94 & 95.70 & 97.16 & 84.40 & 110.28 & 13.80 & 104.87 & 28.80 & 86.48 & 1.30 & 110.12 & $\begin{array}{ll}2 & 10.75\end{array}$ & 95.00 & 53.80 & 114.76 \\
\hline $\mathrm{N}$ & 7.10 & 92.19 & 68.50 & 104.39 & 4.50 & 89.42 & 6.20 & 88.37 & 10.40 & 110 & 26.60 & 89.67 & 2.20 & & 4.11 & 87.80 & 38.29 & 100.27 \\
\hline Piauí & 9.10 & 97.13 & 7.40 & 3.16 & 95.90 & 98.45 & 0.30 & 99.33 & 10.90 & 109.54 & 28.70 & 86.63 & 1.20 & 111.90 & 5.46 & 89.26 & 51.55 & 112.65 \\
\hline , & 15.00 & 111.70 & 80.70 & 8.03 & 96.50 & 102.32 & 80.90 & 100.93 & 15.80 & 101.65 & 25.20 & 91 & .70 & 103.02 & $2 \quad 10.52$ & 94.75 & 39.29 & 101.21 \\
\hline Rio & .80 & 3.68 & 78.50 & 57 & 6.20 & 100 & 78.40 & & 11.50 & 10 & 17.60 & 102 & 2.90 & & 11.97 & 96.32 & 52.01 & 113.09 \\
\hline Paraíba & .30 & 0.09 & 73.80 & 0.31 & 5.80 & 97.80 & 80.60 & 100.13 & 14.50 & 103.74 & 24.00 & 93.44 & 1.90 & & 8.08 & 92.10 & 49.93 & 111.15 \\
\hline the & 12.10 & 104.54 & 9.60 & 5.61 & 95.70 & 97.16 & 7.40 & 91.58 & 18.10 & 97.95 & 24.80 & 92.28 & 2.70 & 85.28 & 9.78 & 93.95 & 30.49 & 92.98 \\
\hline lagoas & 7.60 & 93.42 & 66.40 & 02.04 & 94.30 & 88.13 & 76.80 & 89.98 & 14.30 & 104.07 & 21.60 & 96.92 & 2.10 & 95.93 & 9.45 & 93.59 & 30.38 & 92.88 \\
\hline & 9.50 & 98.11 & 74.70 & 11.32 & 96.20 & 100.38 & 80.30 & 99.33 & 20.10 & 94.73 & 20.10 & 99.10 & 1.50 & 106.57 & 10.25 & 94.46 & 37.88 & 99.89 \\
\hline IId & 9.40 & 97.87 & 69.80 & 105.84 & 6.20 & 100.38 & 3.20 & 107.08 & 17.50 & 98.92 & 24.90 & 92.14 & 1.70 & 103.02 & 8.42 & 92.47 & 29.56 & 92.12 \\
\hline Minas & 9.60 & 98.36 & 63.50 & 98.80 & 97.60 & 109.41 & 79.10 & 96.12 & 17.20 & 99.40 & 20.70 & 98.23 & 1.90 & 99.47 & 19.88 & 104.90 & 27.59 & 90.27 \\
\hline Espírito Santo & 13.20 & 107.26 & 66.90 & 102.60 & 96.50 & 102.32 & 73.60 & 81.43 & 18.70 & 96.98 & 22.10 & 96.20 & 1.60 & 104.80 & $\begin{array}{ll}0 & 19.97\end{array}$ & 104.99 & 28.00 & 90.65 \\
\hline & 14.50 & 110.47 & 5.20 & 111.88 & 97.40 & 108.12 & 84.90 & 111.62 & 25.10 & 86.68 & 7.60 & 117.22 & 2.30 & 92.38 & 19.83 & & 17.71 & 81.04 \\
\hline São F & 4.50 & 110.47 & 70.70 & 106.84 & 8.20 & 113.28 & 86.90 & 116.96 & 22.70 & 90.55 & 11.70 & 111.28 & 1.60 & 104.80 & $\begin{array}{ll}0 & 28.59\end{array}$ & 114.34 & 21.56 & 84.64 \\
\hline Paraná & 3.20 & 107.26 & 8.30 & 92.98 & 7.70 & 110.06 & 77.40 & 91.58 & 14.00 & 104.55 & 22.10 & 96.20 & 1.80 & 101.25 & $5 \quad 24.27$ & 109.66 & 35.55 & 97.71 \\
\hline
\end{tabular}




\begin{tabular}{|c|c|c|c|c|c|c|c|c|c|c|c|c|c|c|c|c|c|c|}
\hline & & 5 & 0 & & 0 & 3 & & & 0 & & 23.90 & & 0 & & & & 1 & 37 \\
\hline & & & & & & & & & & & & & & & & & & 72 \\
\hline & 0 & 4 & 0 & 5 & 0 & & 0 & 1 & 0 & & & & 30 & & & & & 8.39 \\
\hline 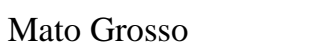 & .80 & 91.44 & 0 & 85 & 95 & 1 & 0 & 8 & 30 & 7 & & & 90 & & & & & 110.57 \\
\hline & & & & & & & & & 0 & & & & 70 & & & & & 97.9 \\
\hline 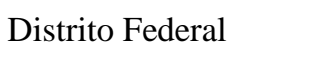 & .00 & 04.29 & 00 & 10 & 9 & 110 & .70 & 119.10 & 28.50 & & 70 & 115 & 70 & & & & & 97.3 \\
\hline & & & & & & & & & & & & & & & & & & \\
\hline Iamuatu beviation & 4.05 & 10.00 & 8.94 & 10.00 & 1.55 & 10.00 & 3.74 & 10.00 & 6.21 & 10.00 & 6.90 & 10.00 & 0.56 & 10.00 & 9.23 & 10.00 & 10.70 & 10.0 \\
\hline
\end{tabular}


Annex 5: Socioeconomic Variables

\begin{tabular}{|c|c|c|c|c|c|c|c|c|c|c|}
\hline$U F$ & 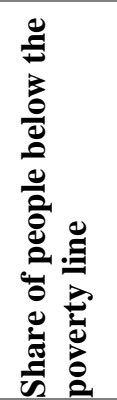 & 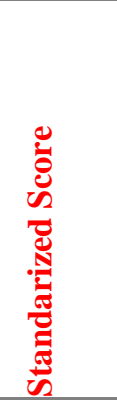 & 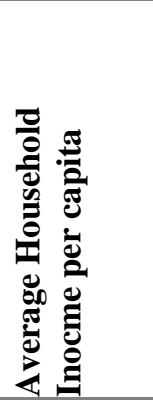 & 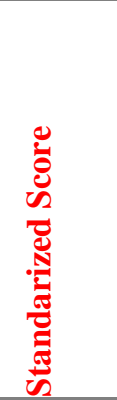 & 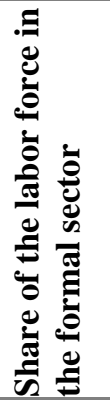 & 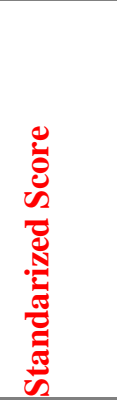 & 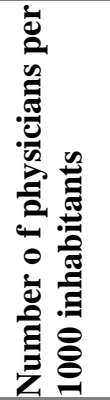 & 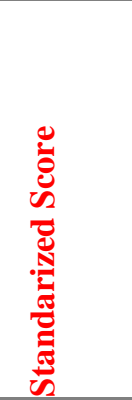 & 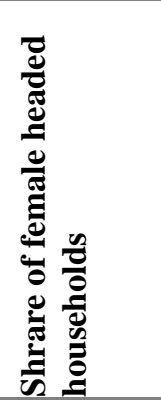 & 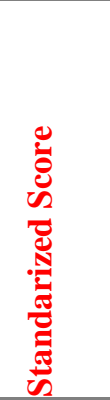 \\
\hline Rondônia & 0.30 & 104.01 & 333.39 & 100.78 & 0.64 & 107.77 & 1.36 & 89.56 & 18.00 & 102.01 \\
\hline Acre & 0.40 & 98.00 & 365.48 & 103.35 & 0.63 & 106.88 & 1.40 & 90.06 & 23.60 & 81.20 \\
\hline Amazonas & 0.40 & 98.00 & 252.94 & 94.32 & 0.63 & 106.88 & 1.50 & 91.30 & 23.20 & 82.68 \\
\hline Roraima & 0.40 & 98.00 & 246.19 & 93.77 & 0.67 & 110.45 & 1.62 & 92.78 & 18.90 & 98.66 \\
\hline Pará & 0.40 & 98.00 & 284.36 & 96.84 & 0.59 & 103.31 & 1.16 & 87.09 & 22.50 & 85.28 \\
\hline Amapá & 0.40 & 98.00 & 269.81 & 95.67 & 0.63 & 106.88 & 1.37 & 89.69 & 19.30 & 97.18 \\
\hline Tocantins & 0.50 & 91.99 & 220.60 & 91.72 & 0.45 & 90.80 & 1.35 & 89.44 & 17.50 & 103.87 \\
\hline Maranhão & 0.60 & 85.98 & 167.12 & 87.42 & 0.36 & 82.77 & 1.06 & 85.85 & 18.70 & 99.41 \\
\hline Piauí & 0.60 & 85.98 & 194.67 & 89.63 & 0.33 & 80.09 & 1.73 & 94.15 & 19.30 & 97.18 \\
\hline Ceará & 0.50 & 91.99 & 233.57 & 92.76 & 0.46 & 91.70 & 1.66 & 93.28 & 20.00 & 94.58 \\
\hline Rio Grande do Norte & 0.50 & 91.99 & 227.96 & 92.31 & 0.56 & 100.63 & 2.44 & 102.94 & 17.60 & 103.50 \\
\hline Paraíba & 0.50 & 91.99 & 216.54 & 91.39 & 0.44 & 89.91 & 2.01 & 97.61 & 18.90 & 98.66 \\
\hline Pernambuco & 0.60 & 85.98 & 264.76 & 95.26 & 0.47 & 92.59 & 2.36 & 101.95 & 19.70 & 95.69 \\
\hline Alagoas & 0.60 & 85.98 & 176.26 & 88.16 & 0.40 & 86.34 & 1.84 & 95.51 & 18.00 & 102.01 \\
\hline Sergipe & 0.50 & 91.99 & 223.15 & 91.92 & 0.50 & 95.27 & 2.44 & 102.94 & 21.80 & 87.89 \\
\hline Bahia & 0.60 & 85.98 & 243.38 & 93.55 & 0.40 & 86.34 & 1.97 & 97.12 & 19.40 & 96.81 \\
\hline Minas Gerais & 0.20 & 110.02 & 343.66 & 101.60 & 0.58 & 102.41 & 2.92 & 108.88 & 19.80 & 95.32 \\
\hline Espírito Santo & 0.20 & 110.02 & 363.60 & 103.20 & 0.56 & 100.63 & 3.04 & 110.37 & 16.60 & 107.21 \\
\hline Rio de Janeiro & 0.20 & 110.02 & 482.71 & 112.77 & 0.71 & 114.03 & 4.15 & 124.12 & 19.10 & 97.92 \\
\hline São Paulo & 0.20 & 110.02 & 517.60 & 115.57 & 0.70 & 113.13 & 3.32 & 113.84 & 17.00 & 105.73 \\
\hline Paraná & 0.20 & 110.02 & 419.00 & 107.65 & 0.59 & 103.31 & 2.65 & 105.54 & 14.80 & 113.90 \\
\hline Santa Catarina & 0.10 & 116.02 & 428.83 & 108.44 & 0.60 & 104.20 & 2.37 & 102.07 & 14.30 & 115.76 \\
\hline
\end{tabular}




\begin{tabular}{|c|c|c|c|c|c|c|c|c|c|c|}
\hline Rio Grande do Sul & 0.20 & 110.02 & 484.37 & 112.90 & 0.55 & 99.74 & 3.38 & 114.58 & 14.20 & 116.13 \\
\hline Mato Grosso do Sul & 0.20 & 110.02 & 370.07 & 103.72 & 0.58 & 102.41 & 2.71 & 106.28 & 15.80 & 110.19 \\
\hline Mato Grosso & 0.20 & 110.02 & 362.41 & 103.11 & 0.52 & 97.06 & 1.82 & 95.26 & 13.20 & 119.85 \\
\hline Goiás & 0.20 & 110.02 & 338.66 & 101.20 & 0.59 & 103.31 & 2.30 & 101.21 & 17.60 & 103.50 \\
\hline \multirow[t]{2}{*}{ Distrito Federal } & 0.20 & 110.02 & 709.29 & 130.97 & 0.79 & 121.17 & 3.54 & 116.56 & 21.80 & 87.89 \\
\hline & 0.37 & 100.00 & 323.72 & 100.00 & 0.55 & 100.00 & 2.20 & 100.00 & 18.54 & 100.00 \\
\hline \multicolumn{11}{|l|}{ National Average } \\
\hline Standard deviation & 0.17 & 10.00 & 124.50 & 10.00 & 0.11 & 10.00 & 0.81 & 10.00 & 2.69 & 10.00 \\
\hline
\end{tabular}

